\title{
AS GARANTIAS DOS FILHOS FRENTE À ALIENAÇÃO PARENTAL
}

\author{
Monaliza Costa de Souza*
}

\section{RESUMO}

AAlienação Parental, reconhecida juridicamente no âmbito da Lei n. 12.318, de 26 de agosto de 2010, apresentou um problema já existente, que já possuía respaldo nas legislações existentes, mas que encontrava dificuldade de identificação e prova. Apesar da lei publicizar o ato de alienação, as dificuldades ainda permanecem, e, enquanto tem sido observada e discutida pelos profissionais da área, ainda presencia muitas crianças e adolescentes vítimas sem uma solução eficiente, que não repercuta para os seus futuros. A sociedade, em contrapartida, parece ainda desconhecer que a criança e o adolescente são pessoas em desenvolvimento e merecem prioridade na observância aos seus direitos e garantias, e respeito a eles. Nesse contexto, entendeu-se importante desenvolver $o$ assunto destas garantias e direitos, face aos princípios do Direito de Família da atualidade, como uma possibilidade de alertar a sociedade e os profissionais das áreas multidisciplinares que estão envolvidos em questões ligadas à Alienação Parental, para estas crianças e adolescentes que podem ver-se afetados psicológica e socialmente de forma profunda, podendo refletir em suas vidas adultas.

\footnotetext{
* Advogada; Pós-graduanda em Direito de Família Contemporâneo e Mediação pela ESADE; Mestranda em Direito pela Universidade Federal do Rio Grande do Sul; Membro do Instituto Brasileiro de Direito de Família - IBDFAM/RS.
} 
Palavras-chave: Alienação $\mathrm{Pa}$ rental. Sindrome da Alienação $P a$ rental (SAP). Crianças. Adolescentes. Direitos. Garantias.

Introdução. 1 A Alienação Parental. 2 A família. 2.1 A tutela da família nas Constituições Federais. 2.2 Breve histórico dos filhos e da família. 3 Os princípios do direito de família com relação aos filhos (crianças ou adolescentes). 3.1 Princípio da Dignidade da Pessoa Humana. 3.2 Princípio da Solidariedade. 3.3 Princípio da Liberdade. 3.4 Princípio da Igualdade. 3.5 Princípio da Convivência Familiar. 3.6 Princípio da Afetividade. 3.7 Princípio do Melhor Interesse da Criança e do Adolescente. 3.8 Princípio da Paternidade Responsável. 4 O sistema protetivo conferido à criança e ao adolescente. 4.1 O Poder Familiar. 4.2 A Guarda. 4.3 Os benefícios trazidos pela Lei da Alienação Parental (Lei ${ }^{\circ}$ 12.318/2010). Conclusão. Referências.

\section{INTRODUÇÃO}

Analisar as garantias das crianças e dos adolescentes, decorrentes dos princípios do direito de família especificamente com relação aos casos de alienação parental é tarefa de grande relevância, principalmente num momento em que as entidades familiares têm ganhado espaço pelos direitos de seus membros e não pela forma como se organizam.

Nesse sentido o presente trabalho traz o desenvolvimento do tema demonstrando aquilo que de mais importante tem a doutrina atual, com algumas referências à história, sobre: a alienação parental; a família; os princípios do direito de família aplicáveis às relações entre os pais e os filhos; e o sistema protetivo conferido à criança e ao adolescente.

Deste modo, será possível criar um panorama que define em que linhas estão traçadas as garantias que crianças e adolescentes têm e que são feridas nos atos de alienação. De modo que, com isso, se possa demonstrar que aos profissionais cabe auxiliar na divulgação desses direitos, e aos pais cabe a real responsabilização pela formação familiar, ato que lhes é livre e, por este motivo, deve ser bem pensado, planejado e assumido com seriedade.

A escolha da bibliografia utilizada foi dentre os autores que têm publicações mais recentes, para que a pesquisa pudesse esboçar um pensamento desta doutrina, não descartando algumas menções a autores já consolidados no âmbito jurídico e alguns estrangeiros que complementam os entendimentos acerca da alienação parental, tema novo no Direito brasileiro.

Pretende-se contribuir para que este tema tenha uma repercussão 
positiva e seja possível aperfeiçoar a aplicação das normas com base numa interpretação que atente para as necessidades da sociedade atual.

\section{A ALIENAÇÃO PARENTAL}

A Alienação Parental é a campanha de desqualificação feita, geralmente, pelo genitor guardião, em desfavor do não guardião, aos seus filhos, com o objetivo de afastálos, podendo em um nível mais grave transformar-se $o$ ato em transtorno psicológico, a síndrome.' Desde 26 de agosto de 2010, com a Lei $\mathrm{n}^{\circ}$ 12.318, a Alienação Parental passou a ser oficialmente reconhecida como um ato de extrema preocupação para o mundo jurídico e a sociedade civil brasileira. Foi através de um projeto de lei apresentado pelo Deputado Regis de Oliveira ${ }^{2}$ que a Alienação Parental ganhou contornos no ordenamento jurídico - a fim de consolidar mais uma forma de cuidado com crianças e adolescentes (além daquelas contidas no Estatuto da Criança e do Adolescente) -, o mesmo diz em sua justificativa que:

\begin{abstract}
Nesse sentido, é de fundamental importância que a expressão "alienação parental" passe a integrar o ordenamento jurídico, inclusive para induzir os operadores do Direito a debater e aprofundar o estudo do tema, bem como apontar instrumentos que permitam efetiva intervenção por parte do Poder Judiciário.
\end{abstract}

$\mathrm{Na}$ Alienação um genitor ou alguém que tenha influência sobre uma criança ou adolescente a convence de que o outro genitor não lhe faz bem, ou não quer a sua companhia, ou de que é necessário que ela se afaste dele. $\mathrm{O}$ que funciona como a "implantação de falsas memórias". ${ }^{3} \mathrm{O}$ objetivo básico de quem aliena é afastar a criança

1 TRINDADE, Jorge. Síndrome de Alienação Parental. In: DIAS, Maria Berenice (Coord.). Incesto e Alienação Parental. 2.ed. rev. atual. e ampl. São Paulo: Revista dos Tribunais, 2010, p. 22.

2 BRASIL. Projeto de Lei $n^{\circ}$ 4.053. Diário Oficial [da] República Federativa do Brasil, Poder Executivo, Brasília, DF, 07 out. 2008. Disponível em: <http://www.camara.gov. br/sileg/integras/601514.pdf $>$. Acesso em: 29 jun. 2011.

3 OLIVEIRA, Euclides de. Alienação Parental. In: VII CONGRESSO BRASILEIRO DE DIREITO DE FAMÍLIA. Família e Responsabilidade - teoria e prática do Direito de Família. Coord. Rodrigo da Cunha Pereira, 7., 2009, Belo Horizonte. Anais... Porto Alegre: Magister/IBDFAM, 2010, p. 232. 
do convívio com alguém que lhe é importante, principalmente com um dos pais, normalmente numa resposta vingativa ao rompimento da relação conjugal. Não se trata de um conceito fechado, é amplo, porque as maneiras de alienação são várias, nesse sentido a Lei $\mathrm{n}^{\circ} 12.318 / 2010^{4}$ estabeleceu:

Art. $2^{\circ}$ Considera-se ato de alienação parental a interferência na formação psicológica da criança ou do adolescente promovida ou induzida por um dos genitores, pelos avôs ou pelos que tenham a criança ou adolescente sob a sua autoridade, guarda ou vigilância para que repudie genitor ou que cause prejuízo ao estabelecimento ou à manutenção de vínculos com este.

Parágrafo único. São formas exemplificativas de alienação parental, além dos atos assim declarados pelo juiz ou constatados por perícia, praticados diretamente ou com auxílio de terceiros:

I - realizar campanha de desqualificação da conduta do genitor no exercício da paternidade ou maternidade;

II - dificultar o exercício da autoridade parental;

III - dificultar contato de criança ou adolescente com genitor;

IV - dificultar o exercício do direito regulamentado de convivência familiar;

$\mathrm{V}$ - omitir deliberadamente a genitor informações pessoais relevantes sobre a criança ou adolescente, inclusive escolares, médicas e alterações de endereço;

VI - apresentar falsa denúncia contra genitor, contra familiares deste ou contra avôs, para obstar ou dificultar a convivência deles com a criança ou adolescente;

De acordo com Môniza Guazzelli, advogada e mestre em Direito, "O que se denomina de Implantação de Falsas Memórias advém, justamente, da conduta doentia do genitor alienador, que começa a fazer com o filho uma verdadeira 'lavagem cerebral', com a finalidade de denegrir a imagem do outro - alienado -, e, pior ainda, usa a narrativa do infante acrescentando maliciosamente fatos não exatamente como estes se sucederam, e ele aos poucos vai se 'convencendo' da versão que lhe foi 'implantada'. O alienador passa então a narrar à criança atitudes do outro genitor que jamais aconteceram ou que aconteceram em modo diverso do narrado" (GUAZZELLI, Mônica. A Falsa Denúncia de Abuso Sexual. In: . Incesto e Alienação Parental - Realidades que a Justiça insiste em não ver: de acordo com a Lei $\mathrm{n}^{\circ} 12.318 / 2010$. 2. ed. rev. atual. e ampl. São Paulo: Revista dos Tribunais/ IBDFAM, 2010, p. 43 - 44)

4 BRASIL. Lei $n^{\circ} 12.318$, de 26 de agosto de 2010. Diário Oficial [da] União, Brasília, DF, 27 de agosto de 2010. Disponível em: <http://www.planalto.gov.br/ccivil_03/_ Ato2007-2010/2010/Lei/L12318.htm>. Acesso em: 17 jun. 2011. 
VII - mudar o domicílio para local distante, sem justificativa, visando a dificultar a convivência da criança ou adolescente com o outro genitor, com familiares deste ou com avôs.

O termo Alienação Parental surgiu com o Psiquiatra e Psicanalista Richard Gardner em 1985', através de um estudo feito sobre a Síndrome da Alienação Parental, a partir da observação de que era uma prática comumente utilizada nas disputas judiciais de guarda pelos pais, que com a clara intenção de benefício próprio programavam os filhos a odiarem $o$ outro genitor sem justificativa. ${ }^{6}$ Embora haja quem duvide da cientificidade dos seus estudos, os conceitos por ele trazidos se perpetuaram e oportunizaram aos profissionais do direito contextualizar aquilo que já ocorria na prática e que os preocupava face à dificuldade de demonstração aos juízes. Joel R. Brandes bem afirma que os Tribunais de Família de Nova Iorque não discutem a Síndrome da Alienação Parental como uma teoria, mas sim consideram a questão no que diz respeito ao fato que a determina como sendo um fator para alteração da guarda. ${ }^{7}$

Richard Ducote, advogado de Nova Orleans (LA), nos Estados Unidos, acredita que a teoria de Gardner é falsa, e seria pró-pedofilia, além de não ser aceita pela comunidade científica. O que se destaca em seu comentário é o fato de que a alegação da Síndrome prejudicaria a ação em face de reais casos de abuso sexual. ${ }^{8}$

5 KRAUSS, Daniel A.; Lieberman, Joel. D. Psychological Expertise in Court: psychology in the courtroom, v. II. United States: Ashgate, 2009. p. 113.

6 LAGO, Vivian de Medeiros; BANDEIRA, Denise Ruschel. A Psicologia e as Demandas Atuais do Direito de Familia. Psicologia Ciência e Profissão, Porto Alegre, 29 (2), p. 290-305, 2009. p. 295.

7 "The Family Court acknowledged that New York cases have not discussed PAS as a theory, but have discussed the issue in terms of whether the child has been programmed to disfavor the noncustodial parent, thus warranting a change in custody." (BRANDES, Joel R.. Parental Alienation. New York Journal, New York, 26 mar. 2000. Disponível em: $<$ http://www.fact.on.ca/Info/pas/brande00.htm\#FN4>. Acesso em: 1 jul. 2011.

8 DUCOTE, Richard. A comment about Dr. Richard Gardner's suicide released by the last man to cross examine him, attorney Richard Ducote. Site Cininnatipas.com. Jun. 2003. Disponível em: $<$ http://cincinnatipas.com/dr-richardgardnerautopsy.html $>$ Acesso em: 23 jun. 2011. 
O que seria de certo modo radical porque apesar da síndrome não ser reconhecida pela sociedade científica de psiquiatria, nos Estados Unidos, o fato ocorre e tem atenção do Tribunal de Nova Iorque conforme afirma Joel R. Brandes ${ }^{9}$ em artigo sobre o assunto publicado no New York Journal, de 26 de março de $2000 . .^{10}$

Estes tipos de críticas refletem o pensamento equivocado, uma perspectiva ideológica que é extremamente estreita. A colaboração de Richard Gardner com a cunhagem do termo (Alienação Parental) e os conceitos trazidos pelo estudo da síndrome despertaram a comunidade jurídica brasileira para um problema também existente no país, e constatado como delicado e de difícil resolução. O que provocou a publicação da Lei $\mathrm{n}^{\circ} 12.318 / 2010$.

9 O mencionado autor diz: "In Matter of JF v. LF, [694 NYS2d 592, 1999 N.Y. Slip Op. 99408 ] the Family Court became the first New York court to discuss PAS [Parental Alienation Syndrome] at length in a custody decision. It pointed out that the theory is controversial, and noted that according to one of the expert witnesses who testified, the syndrome is not approved as a term by the American Psychiatric Society, and it is not in DSM-IV as a psychiatric diagnosis." (BRANDES, Joel R.. Parental Alienation. New York Journal, New York, 26 mar. 2000. Disponível em: <http://www.fact.on.ca/Info/ pas/brande00.htm\#FN4>. Acesso em: 01 jul. 2011.).

$10 \mathrm{~A} \mathrm{Ph}$. D Reena Sommer, em artigo publicado em meio eletrônico, confirma tal raciocínio, complementando que o conteúdo da pesquisa de Richard Gardner tem sido objeto de validação pelo meio acadêmico e que aqueles que entendem seu estudo de maneira negativa, como uma defesa à pedofilia, tem, nas suas palavras, uma perspectiva ideológica estreita e resistente à razão: “[...] Dr. Gardner's early writings are now supported by empirical research on PAS conducted by numerous academics, thus adding credence to PAS's validity and existence. Nevertheless, there are some who have chosen to misinterpret Dr. Gardner's writings by suggesting that he advocated pedophilia and placing children at risk with their abusers. This clearly is not true since Dr. Gardner stipulates in his papers that allegations of abuse that are frequently made in custody disputes must have no prior history, nor upon investigation are they to be found to have any basis. These types of criticisms are reflective of misguided thinking, ignorance and an ideological perspective that is extremely narrow and resistant to reason." (SOMMER, Reena. Parental Alienation Syndrome. Divorcing Mistakes.com, Texas, 2004. Disponível em: <http://www.divorcingmistakes.com/articles/PASreview. pdf $>$. Acesso em 01 jul. 2011.). 
O Tribunal do Rio Grande do Sul, desde 2006 tem precedentes a respeito do assunto, ${ }^{11}$ seguem alguns deles, anteriores à Lei:

\section{GUARDA. SUPERIOR INTERES- SE DA CRIANÇA. SÍNDROME DA ALIENAÇÃo PARENTAL.} Havendo na postura da genitora indícios da presença da síndrome da alienação parental, o que pode comprometer a integridade psicológica da filha, atende melhor ao interesse da infante, mantê-la sob a guarda provisória da avó paterna. Negado provimento ao agravo. (segredo de justiça) (Agravo de Instrumento $\mathrm{N}^{\circ}$ 70014814479, Sétima Câmara Cível, Tribunal de Justiça do RS, Relator: Maria Berenice Dias, Julgado em 07/06/2006) (grifou-se).

DESTITUIÇÃO DO PODER FAMILIAR. ABUSO SEXUAL. SÍNDROME dA ALIENAÇÃo PARENTAL. Estando as visitas do genitor à filha sendo realizadas junto a serviço especializado, não há justificativa para que se proceda à destituição do poder familiar. A denúncia de abuso sexual levada a efeito pela genitora, não está evidenciada, havendo a possibilidade de se estar frente à hipótese da chamada síndrome da alienação parental. Negado provimento. (SEGREDO DE JUSTIÇA) (Agravo de Instrumento $N^{\circ} 70015224140$, Sétima Câmara Cível, Tribunal de Justiça do RS, Relator: Maria Berenice Dias, Julgado em 12/07/2006) (grifou-se).

APELAÇÃO CÍVEL. MÃE FALECIDA. GUARDA DISPUTADA PELO PAI E AVÔS MATERNOS. SÍNDROME DE ALIENAÇÃO PARENTAL DESENCADEADA PELOS AVÔS. DEFERIMENTO DA GUARDA AO PAI. 1. Não merece reparos a sentença que, após o falecimento da mãe, deferiu a guarda da criança ao pai, que demonstra reunir todas as condições necessárias para proporcionar à filha um ambiente familiar com amor e limites, necessários ao seu saudável crescimento.

2. A tentativa de invalidar a figura paterna, geradora da síndorme de alienação parental, só milita em desfavor da criança e pode ensejar, caso persista, suspensão das visitas aos avôs, a ser postulada em processo próprio. NEGARAM PROVIMENTO. UNÂNIME. (Apelação Cível No

11 Precedentes localizados no site do Tribunal de Justiça do Rio Grande do Sul através da pesquisa de jurisprudência pelo termo "alienação parental". Disponível em: $<\mathrm{http}: / /$ www 1.tjrs.jus.br/busca/?q=aliena\%E7\%E3o+parental\&tb=jurisnova\&pesq=ementari o\&partialfields $=\% 28$ TipoDecisao $\% 3 \mathrm{Aac} \% 25 \mathrm{C} 3 \% 25 \mathrm{~B} 3 \mathrm{rd} \% 25 \mathrm{C} 3 \% 25 \mathrm{~A} 30 \% 7 \mathrm{CTipoD}$ ecisao\%3Amonocr\%25C3\%25A1tica\%29\&requiredfields $=\&$ as_q=\&ini $=20>$ Acesso em: 01 jul. 2011. 
70017390972, Sétima Câmara Cível, Tribunal de Justiça do RS, Relator: Luiz Felipe Brasil Santos, Julgado em 13/06/2007) (grifou-se).

\section{AGRAVO DE INSTRUMEN-} TO. AÇÃO DE ALTERAÇÃO DE GUARDA DE MENOR. DECISÃO QUE RESTABELECEU AS VISITAS PATERNAS COM BASE EM LAUDO PSICOLÓGICO FAVORÁVEL AO PAI. PREVALÊNCIA DOS INTERESSES DO MENOR. Ação de alteração de guarda de menor em que as visitas restaram reestabelecidas, considerando os termos do laudo psicológico, por perita nomeada pelo Juízo, que realizou estudo nas partes envolvidas. Diagnóstico psicológico constatando indícios de alienação parental no menor, em face da conduta materna. Contatos paternofiliais que devem ser estimulados no intuito de preservar a higidez física e mental da criança. Princípio da prevalência do melhor interesse do menor, que deve sobrepujar o dos pais. NEGARAM PROVIMENTO AO AGRAVO DE INSTRU-
MENTO. (Agravo de Instrumento $\mathrm{N}^{\circ}$ 70028169118, Sétima Câmara Cível, Tribunal de Justiça do RS, Relator: André Luiz Planella Villarinho, Julgado em 11/03/2009) (grifou-se).

Os precedentes colacionados revelam alguns pontos importantes: a alienação já ocorria, mesmo antes do advento da lei, normalmente em processos de guarda, sendo observados pelos juízes na busca pelo melhor interesse da criança.

Lenita Duarte, ${ }^{12}$ psicóloga, afirma que a ocorrência da alienação se dá normalmente em decorrência de processos de divórcio que geram desgaste muito grande, mas ao mesmo tempo respostas diferentes de pais e filhos. Para a autora a questão complica quando um dos ex-cônjuges reagem de forma hostil, com violência (ainda que não física), e passam a inviabilizar a relação de parentalidade do outro com o filho, que acaba por tornar-se uma arma de vingança, num momento em que,

12 DUARTE, Lenita Pacheco Lemos. Qual a posição da criança envolvida em denúncias de abuso sexual quando o litígio familiar culmina em situações de alienação parental: inocente, vítima ou sedutora?. In: . Incesto e Alienação Parental - realidades que a Justiça insiste em não ver. Coordenação de Maria Berenice Dias. São Paulo: Editora Revista dos Tribunais, 2010, p. 104. 
em meio à discussão dos pais, se vê confuso e inseguro.

De acordo com o advogado Euclides de Oliveira ${ }^{13}$ a complicação de um processo de divórcio se dá mais precisamente no que diz respeito à guarda e convivência, pois em não havendo filhos a discussão recai sobre o patrimônio.

Nesse sentido é possível depreender-se que, quando não há filhos o processo, por mais que seja doloroso e dificultado, não demanda a convivência prolongada do casal, como ocorre no caso de haver filhos comuns. A própria manutenção do vínculo de parentalidade prolonga o sentimento de perda, porque faz com que o convívio entre os ex-cônjuges seja de certa forma inevitável, e, dependendo do caso, pode gerar um desejo de vingança, como detectado pela psicóloga Lenita Duarte no texto mencionado acima.

Sílvio de Salvo Venosa confirma essa ideia de que a alienação é um mal que pode ser prejudicial tanto para os filhos quanto para o genitor alienado:

\begin{abstract}
"A síndrome da alienação parental deve ser vista como uma moléstia. Em muitas situações o alienador não tem consciência plena do mal causado. Sua intenção é mais do que denegrir, destruir 0 outro genitor perante os filhos. Se necessário, o juiz determinará realização de perícia psicológica ou biopsicossocial (art. $5^{\circ}$ da Lei $n^{\circ} 12.318 / 2010$ ). A escolha do profissional capacitado para essa perícia será essencial, podendo ser realizada por equipe multidisciplinar. Psicólogos, psiquiatras, pedagogos, assistentes sociais poderão participar do exame. Provada a existência de desvio psicológico, essa sociopatia é sumamente prejudicial para os filhos e o genitor inocente."
\end{abstract}

Usar o filho, como instrumento de agressão, o induzindo a odiar o outro genitor, denota a imaturidade em lidar com fatos normais à realidade atual, como é o caso da separação. A criança e o adolescente nem sempre conseguem discernir que está sendo manipulado. Além de que o alienador se esquece de que a criança ou o adolescente ainda estão em processo de desenvolvimento e, portanto, são

13 OLIVEIRA, Euclides de. Alienação Parental. In: III CONGRESSO BRASILEIRO DE DIREITO DE FAMÍLIA - Família e Responsabilidade: teoria e prática do direito de família, 7., 2009, Belo Horizonte. Anais... Porto Alegre: Magister/IBDFAM, 2010, p. 231. 
indivíduos frágeis, não se devendo exigir deles que escolham nas suas relações de afeto, principalmente quando se fala de pai e mãe. ${ }^{14}$

A relação da criança e do adolescente com a família, seu núcleo familiar (pai e mãe, por exemplo), é de extrema relevância para a sua formação como indivíduo dentro da sociedade. Se há um mal ocorrendo dentro deste, mais do que nunca o jurista precisa observar todo o delineamento do problema sobre diferentes óticas. Nesse sentido, é preciso tirar um pouco o foco no estudo do instituto da Alienação, para visualizar a criança, dentro do seio familiar, e os seus direitos.

\section{A FAMÍLIA}

Os conceitos relativos à família sofrem constantemente modificação, tanto que ao longo dos anos esta evolução foi ganhando plano nas Constituições. Aos poucos as relações familiares foram sendo abarcadas pelo texto constitucional, que passou a tutelá-las, ampliando a sua proteção, mesmo sem acompanhar exatamente o ritmo da evolução social, mais acelerada que a legislativa. ${ }^{15}$

\subsection{A tutela da família nas \\ Constituições Federais}

Só as Constituições de 1934, 1937 e 1946, das sete anteriores à de 1988 , reservaram espaço para a família, porém as disposições diziam respeito fundamentalmente ao instituto do casamento do que propriamente às garantias concedidas aos seus integrantes. Aquela que chegou mais próximo de constitucionalizar alguma garantia decorrente da constituição familiar foi a de 1937, que falava sobre o dever dos pais de educar os filhos, fossem eles naturais ou legítimos, e a possibilidade de punição pelo abandono moral, intelectual ou físico. Vejam-se os artigos:

Art 125 - A educação integral da prole é o primeiro dever e o direito natural dos pais. $O$ Estado não será estranho a esse dever, colaborando, de maneira principal ou subsi-

14 PEZZELLA, Maria Cristina Cereser; SILVA, Fernanda Pappen da. Os Seres Sujeitos de Direitos em Família. In: SILVA FILHO, José Carlos Moreira da; PEZZELLA, Maria Cristina Cereser (coords.). Mitos e Rupturas no Direito Civil Contemporâneo. Rio de Janeiro: Lumen Juris, 2008, p. 350.

15 LÔBO, Paulo. Direito Civil: famílias. 4. ed. São Paulo: Saraiva, 2011, p. 17. 
diária, para facilitar a sua execução ou suprir as deficiências e lacunas da educação particular.

Art 126 - Aos filhos naturais, facilitando-lhes o reconhecimento, a lei assegurará igualdade com os legítimos, extensivos àqueles os direitos e deveres que em relação a estes incumbem aos pais.

Art 127 - A infância e a juventude devem ser objeto de cuidados e garantias especiais por parte do Estado, que tomará todas as medidas destinadas a assegurar-lhes condições físicas e morais de vida sã e de harmonioso desenvolvimento das suas faculdades.

O abandono moral, intelectual ou físico da infância e da juventude importará falta grave dos responsáveis por sua guarda e educação, e cria ao Estado o dever de provêlas do conforto e dos cuidados indispensáveis à preservação física e moral.

Aos pais miseráveis assiste o direito de invocar o auxílio e proteção do Estado para a subsistência e educação da sua prole.
A Constituição de 1946 tratou em seu art. 164 da obrigatoriedade de assistência à infância e adolescência, mas não especificou garantia aos filhos.

De acordo com Leonardo Barreto Moreira Alves:16 "Até o advento da Constituição Federal de 1988, o conceito jurídico de família era extremamente limitado e taxativo, pois o Código Civil de 1916 somente conferia o status familiae àqueles agrupamentos originados do instituto do matrimônio."

Foi, então, com a Constituição Federal de 1988 que a revolução do Direito de Família teve seu marco, através do reconhecimento da família aberta e plural - advinda do casamento, da união estável ou da monoparentalidade. ${ }^{17}$ Além disso, ela também consagrou o princípio da igualdade entre homens e mulheres e reconheceu a igualdade entre os filhos (arts. $5^{\circ}$, inciso I, e 227, $\S 6^{\circ}$ da Constituição Federal de 1988) independentemente de sua origem. ${ }^{18}$

16 ALVES, Leonardo Barreto Moreira. Temas Atuais de Direito de Família - atualizado de acordo com as leis de números 12.004/09 e 12.010/09. Rio de Janeiro: Lumen Juris, 2010 , p. 1.

17 THOMÉ, Liane Maria Busnello. Dignidade da pessoa humana e mediação familiar. Porto Alegre: Livraria do Advogado, 2010, p. 17.

18 MADALENO, Rolf. Curso de Direito de Familia. 2. ed. rev. e atual. Rio de Janeiro: Forense, 2008, p. 3. 


\subsection{Breve histórico dos filhos e da família}

Num panorama, vale lembrar que os filhos, até a Constituição de 1988, possuíam direitos restritos, e, antes, sequer direitos tinham. $\mathrm{Na}$ Antiguidade Clássica, em Roma, por exemplo:

[...] o pater dispunha sobre o filho do desumano jus vitae et necis, direito de vida e morte, portanto, o direito de matá-lo, ou de transferi-lo a outrem in causa mancipi e o de entregá-lo como indenização, mediante ius noxae dandi. No âmbito patrimonial, o filho era equiparado ao escravo, servus, sem qualquer bem patrimonial, pois tudo que por ele era adquirido integrava o patrimônio do pater. $^{19}$

Além disso, nessa mesma Roma, da Antiguidade Clássica, o princípio da família não era o afeto, que, embora pudesse existir, não importava ao direito. ${ }^{20} \mathrm{~A}$ formação familiar de Roma não era restrita à consanguinidade, assim é importante transcrever o que diz o Professor Doutor Carlos Silveira Noronha ${ }^{21}$ a respeito da família romana:

O paterfamilias, que unificava sob sua autorictas todos os membros da família, desfrutava em relação a eles de direitos de ordem e de ordem patrimonial, tais como a patria potestas ou o poder sobre os filhos e netos masculinos; a manus ou o poder sobre as mulheres casadas com o pater ou com seus descendentes; o mancipium ou o poder sobre as pessoas a ele vendidas como escravos (in mancipi); e ainda, a dominica potestas, que era o poder geral sobre os escravos. Sobre os seus dependentes ou filii familias, o pater tinha o ius vitae et necis, o ius exponendi, o ius vendendi e o ius noxae dandi, ou sejam, respectivamente, os direitos de vida e de morte; de abandonar o filho infante; de vender as pessoas

19 NORONHA, Carlos Silveira. Da instituição do Poder Familiar, em perspectiva histórica, moderna e pós-moderna. Revista da Faculdade de Direito da Universidade Federal do Rio Grande do Sul. Porto Alegre: UFRGS, nº 26, p. 89 - 120, dez. 2006, p. 90.

20 NORONHA, op. cit., p. 97.

21 NORONHA, Carlos Silveira. Conceito e fundamentos de família e sua evolução na área jurídica. Revista da Faculdade de Direito da Universidade Federal do Rio Grande do Sul. Porto Alegre: UFRGS, nº 10, p. 161 - 174, jul. 1994, p. 163. 
sob o seu poder; de livrar-se do filho que comete delito; abandonando-o em favor das parte lesada, através da noxae delitio. Estes poderes (direitos) do pater foram sendo amenizados, com o passar dos tempos, sendo os dois últimos finalmente abolidos no período imperial, por Justiniano, sob a influência da ética cristã.

Sob essa mesma ótica Jorge Shiguemitsu Fujita lembra o que Caio Mário da Silva Pereira disse: "A família romana, chefiada pelo pater familias, ao invés de se fundar no princípio ético da afeição, era calcada no princípio da autoridade." ${ }^{22}$

A grande autoridade que o chefe de família possuía apenas demonstrava a pouca ou nenhuma autonomia que os demais membros da família tinham. $\mathrm{O}$ reconhecimento de direitos à época, portanto, vislumbrava garantir a autoridade e patrimonialidade do pater, porque nele estava fundada a família. Pontes de Miranda ${ }^{23}$ complementa tal ideia dizendo que:
[...] A patria potestas dos Romanos era dura criação de direito despótico, e não tinha correlação com os deveres do pai para com o filho. É certo que existiam deveres, porém esses quase só eram providos da moral. Juridicamente, a patria potesta constituía espécie de direito de propriedade.[...]

Com a evolução do direito de família o modelo familiar foi se alterando até alcançar o que se tem atualmente: pais e filhos, e a que se chama de família nuclear, célula básica da sociedade, mais coesa e unida pelo afeto, não mais calcada na autoridade do pai. O Professor Doutor Carlos Silveira Noronha ${ }^{24}$ muito bem observou que:

[...] Nenhuma dúvida mais pode residir no sentido de que a grande ou numerosa família reunida sob o regime da agnatio romana ou da sippe do direito germânico, não tem mais espaço no mundo moderno,

22 PEREIRA, Cáio Mário da Silva. Reconhecimento de paternidade e seus efeitos. 5. ed. Rio de Janeiro: Forense, 1996, p. 8 apud FUJTA, 2009, p. 13.

23 PONTES DE MIRANDA. Tratado de Direito Privado - Parte Especial - Tomo IX - Direito de Família: Direito parental. Direito Protetivo. 4. ed. São Paulo: Revista dos Tribunais, 1974, p. 106.

24 NORONHA, Carlos Silveira. Conceito e fundamentos de família e sua evolução na área jurídica. Revista da Faculdade de Direito da Universidade Federal do Rio Grande do Sul. Porto Alegre: UFRGS, nº 10, p. 161 - 174, jul. 1994, p. 168. 
onde surge a família conjugal, ou a família nuclear, centrada na tríade pai-mãe-filho, que vem substituindo a ideia de autoridade pela do companheirismo solidário e da afetividade. Sob o enfoque do respeito e sobrelevação dos direitos humanos que as codificações políticas modernas vêm consagrando $[\ldots]$ eis que deve a família preparar-se para enfrentar conjuntamente os embates acima denunciados, que lhe são impostos pela nova realidade social neste passo vigente. (grifou-se)

Na mesma linha de pensamento é o que diz Clóvis Beviláqua: ${ }^{25}$

Os fatores de constituição da família são: em primeiro lugar, o instinto genesíaco, o amor, que aproxima os dois sexos; em segundo, os cuidados exigidos para a conservação da prole, que tornam mais duradoura a associação do homem e da mulher, e que determinam o surto de emoções novas, a filoprogênie e o amor filial, entre procriadores e procriados, emoções essas que tendem todas a consolidadar a associação familiar.
Embora no conceito exposto pelo autor haja a determinação da aproximação entre os dois sexos, homem e mulher, como uma remessa à família tradicional, formada pelo casamento, é importante destacar que atualmente a família tem outras constituições, quais sejam:

[...] monoparental (um dos pais e sua prole, ainda advinda da adoção), mosaico (é a família monoparental que passa a ter um novo membro, madrasta ou padrasto, por exemplo), anaparental (constituída por uma ou mais pessoas, sendo ou não parentes entre si, estruturadas com um propósito familiar), ou homoparental (resultante de relações homoafetivas) $[\ldots]^{26}$

Assim, sob esta nova ótica da família:

[...] A tutela jurídica ultimamente tem sido direcionada no sentido de resguardar a entidade familiar, considerando sua subjetividade, promovendoefetivamentea dignidade individual de seus membros, sempre permeado pela figura principal do

25 BEVILAQUA, Clovis. Direito da Família. 7. ed. São Paulo: Editora Rio, 1976. p.17. 26 SOUZA, Monaliza Costa de et al. O papel do advogado na alienação parental. In: . Família contemporânea: uma visão interdisciplinar. Coordenação de Ivone M. Candido Coelho de Souza. Porto Alegre: IBDFAM: Letra\&Vida, 2011, p. 169. 
afeto, e baseados na solidariedade e na mútua assistência. ${ }^{27}$

O que Clóvis Beviláqua afirma no trecho mencionado anteriormente é um dos pontos-chave que este estudo quer destacar, a respeito da importância na constituição familiar estar formada em torno da intenção do casal de viver junto, para compartilhar e praticar o amor que sentem, bem como para terem filhos e cuidarem dos mesmos juntos. Parece subjetivo mas isso quer dizer que ao se propor a constituir uma família, com ou sem filhos, os indivíduos que componham a mesma se dispõem a viver mediante respeito e cuidado, é como a missão mencionada Pontes de Miranda ${ }^{28}$ no trecho de sua obra abaixo transcrito:

O pátrio poder moderno é conjunto de direitos concedidos ao pai ou à própria mãe, a fim de que, graças a eles, possa melhor desempenhar a sua missão de guardar, defender e educar os filhos, formando-os e robustecendo-os para a sociedade e a vida. A expressão 'poder' tem sentido de exteriorização do querer, não de imposição e violência [...].

É nesse sentido que Leonardo Barreto Moreira Alves ${ }^{29}$, a respeito da evolução da família, assevera que “[...] a família advinda da Constituição Federal de 1988 tem o papel único e específico de fazer valer, no seu seio, a dignidäde dos seus integrantes como forma de garantir a felicidade pessoal de cada um deles."

O mesmo autor colabora com o entendimento de que com a Constituição Federal de 1988 o conceito de família sofreu profundas alterações. Isso se deu através de alguns princípios que a Carta Magna trouxe, sejam eles: o princípio do reconhecimento da união estável (art. $226, \S 3^{\circ}$ ) e o princípio da família monoparental (art. 226, § $4^{\circ}$ ), que, nas palavras do autor, quebraram

27 Idem, ibidem.

28 PONTES DE MIRANDA. Tratado de Direito Privado - Parte Especial - Tomo IX - Direito de Família: Direito parental. Direito protetivo. 4. ed. São Paulo: Revista dos Tribunais, 1974, p. 106-107.

29 ALVES, Leonardo Barreto Moreira. Temas Atuais de Direito de Família - atualizado de acordo com as leis de números 12.004/09 e 12.010/09. Rio de Janeiro: Lumen Juris, 2010, p. 99. 
- monopólio do casamento como único legitimador da família. Além do princípio da dignidade da pessoa humana (art. $1^{\circ}$, inc. III), que trouxe a promoção pessoal dos componentes da entidade familiar, preconizando, por isso, o afeto sobre a antiga constituição familiar com base na constituição jurídica. ${ }^{30} \mathrm{E}$ complementa dizendo que:

Consubstanciando o princípio vetor da dignidade da pessoa humana no seu art. $1^{\circ}$, III, a Carta Magna provocou uma autêntica revolução no Direito Civil como um todo, dando ensejo a um fenômeno conhecido como despatrimonialização ou personalização desse ramo do Direito. No campo específico do Direito de Família, verifica-se que a entidade familiar passa a ser encarada como uma verdadeira comunidade de afeto e entreajuda e não mais como uma fonte de produção de riqueza como outrora. É o âmbito familiar o local mais propício para que o indivíduo venha a obter a plena realização da sua dignidade enquanto ser humano, porque o elo entre os integrantes da família deixa de ter conotação patrimonial para envolver, sobretudo, o afeto, o carinho, amor e a ajuda mútua. ${ }^{31}$

Ou seja, com o tempo a família foi adquirindo um espaço diferente na sociedade, em que a importância do seu patrimônio foi sendo substituída pela de cada um de seus membros. O ser humano, hoje, assim como vê a concepção eudemonista ${ }^{32}$, busca a felicidade e a liberdade em suas relações, não cabendo mais aquela figura familiar que juntava esforços para uma conquista primordialmente econômica. ${ }^{33}$

30 ALVES, Leonardo Barreto Moreira. Temas Atuais de Direito de Família - atualizado de acordo com as leis de números 12.004/09 e 12.010/09. Rio de Janeiro: Lumen Juris, 2010, p. 1-2.

31 ALVES, op. cit., p. 8-9.

32 FACHIN, Luiz Edson. As Intermitências da Vida - O Nascimento dos Não-Filhos à Luz do Código Civil Brasileiro. $1^{\text {a }}$ ed. Rio de Janeiro: Forense, 2007.

33 É importante destacar que não se tem a pretensão, aqui, de dizer que todas as disposições legais patrimoniais deveriam ser substituídas. As disposições a respeito da sucessão, de ordem patrimonial, por exemplo, são necessárias à própria organização social. O que há de se observar é a preocupação que se modificou ao longo dos anos em substituir o objetivo patrimonial da constituição familiar, pelo objetivo maior do afeto. As uniões, em sua maioria, ocorrem fundadas no objetivo de conjugação de vida, de troca afetiva, de busca pela felicidade. É o que se entende com base na leitura dos autores mencionados nessa pesquisa. 
Isso demonstra o porquê de nos últimos anos ter-se discutido tanto problemas que já ocorriam há muito, mas que ainda não eram vistos com tanta relevância e preocupação como o são na atualidade, como é o caso da alienação parental. Seja porque a família de hoje tem resguardada a dignidade de seus indivíduos, porque os filhos têm garantias e direitos iguais aos dos pais (observadas as suas peculiaridades), ou porque a criança hoje é vista como um sujeito de direitos garantidos pelo Estatuto da Criança e do Adolescente. É o que destaca o trecho a seguir:

Nesse contexto histórico, a criança despontou como sujeito de direitos e, consequentemente, seus interesses passaram a ser priorizados, podendo, inclusive, contrapor-se aos interesses de seus genitores, uma vez que a primazia é pelo bem-estar da criança. ${ }^{34}$ (grifo nosso).

É sob esses aspectos da vida em comum que a Constituição de 1988 estabeleceu princípios que norteiam tal convivência, seguem, portanto, aqueles relevantes ao entendimento do assunto em estudo.

\section{OS PRINCÍPIOS DO DIREITO DE FAMÍLIA COM RELAÇÃO AOS FILHOS (CRIANÇAS OU ADOLESCENTES)}

Por tratar-se a alienação de problema que afeta diretamente a criança ou adolescente, no seio familiar, até o momento vem se delineando o conteúdo da família e dos seus componentes. Assim, é importante lembrar que a própria Constituição Federal de 1988 trouxe em seu texto um capítulo dedicado à família, à criança, ao adolescente, ao jovem e ao idoso (arts. 226 a 230), sinal efetivo da preocupação do Estado, principalmente com os membros mais frágeis dessa entidade. $O$ art. 226 em seu $\S 7^{\circ}$ da Carta Magna cita dois princípios de suma importância quando o assunto é criança e adolescente: o princípio da dignidade da pessoa humana

34 PEZZELLA, Maria Cristina Cereser; SILVA, Fernanda Pappen da. Os Seres Sujeitos de Direitos em Família. In: SILVA FILHO, José Carlos Moreira da; PEZZELLA, Maria Cristina Cereser (coords.). Mitos e Rupturas no Direito Civil Contemporâneo. Rio de Janeiro: Lumen Juris, 2008, p. 325. 
(aplicado a todos os indivíduos) e o da paternidade responsável. Mas existem outros que podem ser extraídos do texto Constitucional, como por exemplo os destacados no art. 227, os princípios: da liberdade (caput), da convivência familiar (caput), da igualdade de filiação $\left(\S 6^{\circ}\right)$ e o princípio da solidariedade familiar no art. 229.

$\mathrm{Na}$ atualidade os princípios têm grande papel no direito, são eles que aproximam as normas existentes da realidade social. Bem colocou o advogado Sérgio Gabriel quando disse que: "O termo princípio, em regra, parece designar o começo ou início de alguma coisa, porém, em termos jurídicos, é muito mais amplo; o princípio quer na verdade alicerçar uma estrutura, garantir a sua existência e a sua aplicabilidade. [...]". ${ }^{35}$

Cabe destacar as esclarecedoras palavras de Paulo Lôbo ${ }^{36}$, que, complementando a explanação acerca da importância dos princípios constitucionais, os classifica como "supor- te fático hipotético necessariamente indetermina e aberto" dependente do intérprete, no caso o juiz, diferente da regra "determinada e fechada" concretizada por uma realidade que leva à sua incidência. $\mathrm{O}$ autor diz, in verbis:

Ainda que não seja este o espaço para se discorrer sobre esses temas, amplamente discutidos no âmbito do direito constitucional e da teoria do direito, perfilhamos o entendimento de que as normas constitucionais, todas com força normativa própria, classificam-se em princípios e regras, distinguindo-se por seu conteúdo semântico e, consequentemente, pelo modo de incidência e aplicação. A regra indica suporte fático hipotético (ou hipótese de incidência) mais determinado e fechado, cuja concretização na realidade da vida leva à sua incidência, confirmando-a $o$ intérprete mediante 0 meio tradicional da subsunção (exemplo, na CF: 'Art. 226, ( $\S 4^{\circ}$ : Entende-se, também, como entidade familiar a comunidade formada por qualquer dos pais e seus descendentes'; ou seja, toda vez que uma pessoa passa

35 GABRIEL, Sérgio. O papel dos princípios no Direito brasileiro e os princípios constitucionais. Jus Vigilantibus, São Paulo, 23 jul. 2007. Disponível em: <http:/jusvi. com/artigos/29789>. Acesso em: 07 jul. 2011.

36 LÔBO, Paulo. Direito Civil: famílias. 4. ed. São Paulo: Saraiva, 2011, p. 57. 
a conviver com um filho, seja ele biológico ou não biológico, ainda que sem a companhia de cônjuge ou companheiro, a regra incidirá para assegurar a constituição de uma entidade familiar; em outras palavras, a norma constitucional incidirá sobre esse suporte fático concreto e o converterá no fato jurídico por ela previsto, que passará a produzir os efeitos jurídicos por ela tutelados). (grifou-se).

E segue dizendo que:

O princípio, por seu turno, indica suporte fático hipotético necessariamente indeterminado $\mathrm{e}$ aberto, dependendo a incidência dele de mediação concretizadora do intérprete, por sua vez orientado pela regra instrumental da equidade, entendida segundo formulação grega clássica, sempre atual, de justiça do caso concreto. Tome-se o exemplo do princípio da dignidade da pessoa humana, referido expressamente no $\$ 7^{\circ}$ do art. 226 da Constituição: o casal é livre para escolher seu planejamento familiar, mas deve fazê-lo em obediência ao princípio da dignidade da pessoa humana, cuja observância confirmará o intérprete apenas em cada situação concreta, de acordo com a equidade, que leva em conta a ponderação dos interesses legítimos e valores adotados pela comunidade em geral. ${ }^{37}$ (grifou-se)

O que Paulo Lôbo coloca tem grande interesse no estudo, porque reafirma qual postura o juiz deve ter mediante um caso, por exemplo de alienação parental. Ele, o juiz, ao receber petição que indica a ocorrência de alienação, a priori observará as situações fáticas concretas conforme os dispositivos da Lei $\mathrm{n}^{\circ}$ 12. 318/2011 que orientam quais as ações que configuram a possibilidade de ocorrência de alienação parental, em seguida ele parte para a avaliação dos princípios envolvidos, para garantir que todos os envolvidos tenham seus direitos fundamentais garantidos.

Nesse sentido, é importante destacar alguns princípios do Direito de Família que reforçam as garantias da criança e do adolescente frente à ocorrência de atos de Alienação Parental, são eles os princípios da: dignidade da pessoa humana, solidariedade familiar, liberdade, igualdade de filiação, afetividade, convivência familiar, e do melhor interesse da criança e do adolescente.

37 LÔBO, Paulo. Direito Civil: famílias. 4. ed. São Paulo: Saraiva, 2011, p. 58. 
Não há como analisar princípio por princípio sem considerar que eles estão todos correlacionados, e que através desta correlação é que eles formam um sistema equilibrado, que garante que a família seja um campo seguro para os seus componentes. Isso significa, de modo geral, que não há família se não há uma motivação afetiva para sua formação, decorrendo desta a solidariedade entre os seus membros, a quem é deferido pelo texto constitucional liberdade $\mathrm{e}$ igualdade, sem deixar de considerar as suas desigualdades ${ }^{38}$, tudo sob a ótica de que todo cidadão merece ter sua dignidade respeitada, pelos demais e pelo Estado. É claro que dizer isto não é garantia de efetividade, mas apenas uma demonstração de que há um modelo ideal abarcado pelos princípios do Direito de Família e que dentro disso algumas atitudes legais podem ser tomadas sob esta ótica. Seguem, portanto, algumas considerações acerca dos princípios mencionados.

\subsection{Princípio da Dignidade da Pessoa Humana}

O princípio da dignidade da pessoa humana faz parte do rol de princípios fundamentais da República Federativa do Brasil, como Estado Democrático de Direito, estando presente no art. $1^{\circ}$, inciso III, da Constituição Federal de 1988. ${ }^{39}$

38 No caso das crianças e dos adolescentes, por exemplo, essa desigualdade se refere ao fato de estes serem pessoas em desenvolvimento.

39 O artigo da Constituição de 1988 em referência diz o seguinte:

Art. $1^{\circ} \mathrm{A}$ República Federativa do Brasil, formada pela união indissolúvel dos Estados e Municípios e do Distrito Federal, constitui-se em Estado Democrático de Direito e tem como fundamentos:

I - a soberania;

II - a cidadania;

III - a dignidade da pessoa humana;

IV - os valores sociais do trabalho e da livre iniciativa;

V - o pluralismo político.

Parágrafo único. Todo o poder emana do povo, que o exerce por meio de representantes eleitos ou diretamente, nos termos desta Constituição. 
Ainda assim o constituinte entendeu por bem reforçar tal princípio nas disposições relativas à família, considerada por ele mesmo com a base da sociedade, deixando-o claro nos dispositivos a seguir:

Art. 226. A família, base da sociedade, tem especial proteção do Estado.

[...]

$\S 7^{\circ}$ - Fundado nos princípios da dignidade da pessoa humana e da paternidade responsável, o planejamento familiar é livre decisão do casal, competindo ao Estado propiciar recursos educacionais $\mathrm{e}$ científicos para o exercício desse direito, vedada qualquer forma coercitiva por parte de instituições oficiais ou privadas.

$\S 8^{\circ}-$ O Estado assegurará a assistência à família na pessoa de cada um dos que a integram, criando mecanismos para coibir a violência no âmbito de suas relações.

Art. 227. É dever da família, da sociedade e do Estado assegurar à criança, ao adolescente e ao jovem, com absoluta prioridade, o direito à vida, à saúde, à alimentação, à educação, ao lazer, à profissionalização, à cultura, à dignidade, ao respeito, à liberdade e à convivência familiar e comu- nitária, além de colocá-los a salvo de toda forma de negligência, discriminação, exploração, violência, crueldade e opressão. (Redação dada Pela Emenda Constitucional $\mathrm{n}^{\circ}$ 65 , de 2010).

[...]

Art. 230. A família, a sociedade e o Estado têm o dever de amparar as pessoas idosas, assegurando sua participação na comunidade, defendendo sua dignidade e bemestar e garantindo-lhes o direito à vida. $\S 1^{\circ}$ - Os programas de amparo aos idosos serão executados preferencialmente em seus lares.

$\S 2^{\circ}$ - Aos maiores de sessenta e cinco anos é garantida a gratuidade dos transportes coletivos urbanos.

A família tem sua proteção como um todo. A cada um de seus membros é designado tratamento digno. Contudo, é possível observar que à criança, ao adolescente e ao idoso a preocupação é especial e mereceu disposições específicas. É também o que destaca Maria Helena Diniz ${ }^{40}$, quando menciona

que constitui [o princípio do respeito à dignidade da pessoa humana] base da comunidade familiar (biológica ou

40 DINIZ, Maria Helena. Curso de Direito Civil Brasileiro, v. 5: Direito de Família. 25. ed. São Paulo: Saraiva, 2010, p. 23. 
socioafetiva), garantindo, tendo por parâmetro a afetividade, o pleno desenvolvimento e a realização de todos os seus membros, principalmente da criança e do adolescente ( $\mathrm{CF}$, art. 227). (grifou-se).

Para a Liane Maria Busnello Thomé41: "o conteúdo do princípio constitucional da dignidade da pessoa humana se relaciona com os direitos fundamentais, significando que, para respeitar a dignidade da pessoa humana, é necessário respeitar os direitos fundamentais dos indivíduos [...]", clara demonstração de que tal princípio é, senão o mais, um dos mais abrangentes.

Mazzoni e Marta ${ }^{42}$ destacaram tal princípio como "valor supremo"43, abarcando em si outros princípios, o que colabora com o entendimento emitido no parágrafo anterior. As autoras, ainda, muito bem lembraram o art. $1^{\circ}$ da Declaração dos Direitos do Homem e do Cidadão, proclamada pela Organização das Nações Unidas de 1948: "Todos os homens nascem livres e iguais em dignidade e direitos". $O$ texto atual, seguindo a evolução, deixou de falar em homens e substituiu a expressão para "seres humanos"

41 THOMÉ, Liane Maria Busnello. Dignidade da pessoa humana e mediação familiar. Porto Alegre: Livraria do Advogado, 2010, p. 47.

42 MAZZONI, Henata Mariana de Oliveira; MARTA, Taís Nader. Síndrome da Alienação Parental. Revista Brasileira de Direito das Familias e Sucessões. Porto Alegre: Magister; Belo Horizonte: IBDFAM, 2007, ano XIII, n 21, bimestral abr/mai 2011, p. 34-35.

43 Tratar o princípio da dignidade humana como valor supremo: "Significa dizer que, no âmbito da ponderação de bens ou valores, o princípio da dignidade da pessoa humana justifica, ou até mesmo exige, a restrição de outros bens constitucionais protegidos, ainda que representados em normas que contenham direitos fundamentais, de modo a servir como verdadeiro e seguro critério para solução de conflitos" (MAZZONI, Henata Mariana de Oliveira; MARTA, Taís Nader. Síndrome da Alienação Parental. Revista Brasileira de Direito das Familias e Sucessões. Porto Alegre: Magister; Belo Horizonte: IBDFAM, 2007, ano XIII, n 21, bimestral abr/mai 2011, p. 34 - 35).

44 ONU. Declaração Universal dos Direitos Humanos. Rio de Janeiro, dez. 2000. Disponível em: <http://unicrio.org.br/img/DeclU_D_HumanosVersoInternet.pdf> Acesso em: 12 jul. 2011. 
A garantia trazida por este de modo a constituir o grupo unidade princípio, como valor supremo, sólida, capaz de resistir às forças aparenta-se como que o referencial exteriores e mesmo de tornar-se ainda para a ordem jurídica lidar com os mais firme em face da oposição vinda demais direitos do cidadão, tanto que há quem diga que trata-se do princípio da dignidade da pessoa humana de fundamento que a Constituição abordou para garantir que cada ser humano constitua sua família sob outros princípios: da solidariedade, da pluralidade familiar, da isonomia, da liberdade e da autonomia de vontade. ${ }^{45}$

\subsection{Princípio da Solidariedade}

Solidariedade ${ }^{46}$ envolve a noção de "mutualidade de interesses e deveres", "laço ou ligação mútua entre duas ou muitas coisas dependentes umas das outras", "compromisso pelo qual as pessoas se obrigam umas pelas outras e cada uma delas por todas", "Condição grupal resultante da comunhão de atitudes e sentimentos, de fora".

Este conceito remete a uma ideia ampla de solidariedade e, nesse sentido, possivelmente, tenha $o$ constituinte o colocado como objetivo fundamental no inciso III do art. $3^{\circ}$.

Pela sua importância este princípio também passou a ser tratado como um princípio de Direito de Família. Nesse âmbito, Paulo Lôbo ${ }^{47}$ entende que a solidariedade entre pais e filhos é construída dentro dos seus próprios valores, mas precisa preservar um mínimo:

Logicamente, a solidariedade familiar é construída sob valores traçados pelos ascendentes em favor dos descendentes. E estes, por seu turno, acabarão por trilhar caminho parecido com aquele que thes foi ensinado. Muito embora o parâmetro da

45 THOMÉ, Liane Maria Busnello. Dignidade da pessoa humana e mediação familiar. Porto Alegre: Livraria do Advogado, 2010, p. 44.

46 SOLIDARIEDADE. In: MICHAELIS Moderno Dicionário da Língua Portuguesa. São Paulo: Melhoramentos, 1998. Disponível em: <http://michaelis.uol.com.br/ moderno/portugues/index.php?lingua $=$ portugues-portugues \&palavra $=$ solidariedade $>$. Acesso em: 13 jul. 2011.

47 LISBOA, Roberto Senise. Manual de direito civil, v. 5: direito de família e sucessões. 5. ed. reform. São Paulo: Saraiva, 2009, p. 15-16. 
solidariedade interna sofra uma oscilação de uma entidade familiar para outra em virtude dos padrões culturais vigentes e da procedência de cada entidade, há um mínimo a ser preservado: os direitos personalíssimos de cada integrante da familia, sua subsistência e a concessão de auxílio para que se possa ter a oportunidade de se atingir o nível de desenvolvimento esperado pelo interessado. Enfim, assistência material e imaterial entre os membros da entidade familiar devem sempre se fazer presentes nas relações jurídicas existentes. (grifou-se)

Assim, aos filhos os pais devem deferir tratamento solidário no sentido de dar o suporte necessário para que eles tenham uma vida digna, com saúde, alimentação, educação, lazer, respeito, liberdade e convivência familiar, assim como dispõe o art. $4^{\circ}$ do Estatuto da Criança e do Adolescente (Lei no 8.069/1990) ${ }^{48}$

\subsection{Princípio da Liberdade}

A liberdade, assim como a solidariedade, faz parte dos objetivos fundamentais da República, no inciso I do art. $3^{\circ}$ da Constituição Federal. Não é princípio difícil de se conceituar, mas é preciso compreender que a liberdade ocorre dentro dos parâmetros legais.

Paulo Lôbo ${ }^{49}$ conceitua tal princípio no âmbito do direito de família, remetendo-se a questões que encontram-se no âmbito das disposições constitucionais e também constantes no Estatuto da Criança e do Adolescente:

O princípio da liberdade diz respeito ao livre poder de escolha ou autonomia de constituição, realização e extinção de entidade familiar, sem imposição ou restrições externas de parentes, da sociedade ou do legislador; à livre aquisição e administração do patrimônio familiar; ao livre planejamento familiar; à livre definição dos modelos educacionais, dos valores culturais e religiosos; à livre formação dos filhos, desde que respeitadas suas dignidades como pessoas humanas; à liberdade de agir, assentada no respeito à integridade física, mental e moral.

$\mathrm{Na}$ Constituição também encontra a liberdade, no seu sentido amplo,

48 BRASIL. Estatuto da Criança e do Adolescente. Diário Oficial da União, Poder Executivo, Brasília, DF, 16 jul. 1990. Disponível em: <http://www.planalto.gov.br/ ccivil_03/Leis/L8069.htm>. Acesso em 13 jul. 2011.

49 LÔBO, Paulo. Direito Civil: famílias. 4. ed. São Paulo: Saraiva, 2011, p. 69. 
amparo no caput do art. $5^{\circ}$, ou no âmbito do Direito de Família, através do art. 226 , no seu $\S 7^{\circ}$, quando fala na liberdade dos indivíduos planejarem suas famílias: se vão se casar, ou viver em união estável, quantos filhos terão, como os educarão. Ocorre que a liberdade familiar é pautada pela garantia aos direitos fundamentais de cada indivíduo, ou seja, cumpre lembrar que a liberdade não significa que um genitor poderá impor ao seu filho a convivência somente com ele, ou que minta, há parâmetros de razoabilidade que devem ser seguidos. porque, conforme dito inicialmente, os princípios e regras referem-se a um sistema equilibrado.

Já no Estatuto da Criança e do Adolescente, o art. 16 faz uma lista do que compreende a liberdade: ir e vir, opinar, se expressar, ter determinada crença, brincar, praticar esportes e divertir-se, participar da vida familiar e comunitária sem discriminação, e outros.

\subsection{Princípio da Igualdade}

A igualdade refere-se tanto à equivalência de tratamento dada aos filhos ( $\S 6^{\circ}$ do art. 227 da Constituição Federal e art. 20 do Estatuto da Criança e do Adolescente), seja qual for a sua origem, seja com relação à mulher e ao homem (inciso I do art. $5^{\circ}, \S 5^{\circ}$ do 226 da Constituição Federal e art. 21 do Estatuto da Criança e do Adolescente).

A igualdade entre homem e mulher, dentro da entidade familiar, foi conquistada com a própria mudança social, em que a mulher foi adquirindo espaço e o homem foi assumindo papéis que antes não lhe eram destinados. A conquista de igualdade foi um processo evolutivo e hoje não cabe dizer que a mulher não possa sustentar o lar ou que o homem não possa cuidar com zelo dos filhos. Carlos Roberto Gonçalves ${ }^{50}$ diz a respeito que:

[...] A regulamentação instituída no aludido dispositivo [art. 226, $\S 5^{\circ}$, da Constituição Federal] acaba com o poder marital e com o sistema de encapsulamento da mulher, restrita a tarefas domésticas e à procriação. $\mathrm{O}$ patriarcalismo não mais se coaduna, efetivamente, com a época atual, em que grande parte dos avanços tecnológicos e sociais está diretamente

50 GONÇALVES, Carlos Roberto. Direito Civil Brasileiro, v. 6: Direito de Família. 8. ed. rev. e atual. São Paulo: Saraiva, 2011, p. 23. 
vinculada às funções da mulher na família e referenda a evolução moderna, confirmando verdadeira revolução no campo social.

No que se refere à filiação esta também modificou-se ao longo dos anos. A liberdade de constituição familiar (art. 226 da Constituição Federal) contribuiu para que a situação do filho não fosse mais vista sob a ótica da sua origem, mas sobre as suas necessidades protetivas. Ou seja:

O Código Civil de 1916 exaltava o casamento civil como único modelo da família legítima e, desta forma, todos os filhos nascidos à margem deste modelo eram considerados ilegítimos e impróprios à proteção social e jurídica. No entanto, assim como a própria família e a condição feminina sofreram intensas transformações, a filiação também percorreu um longo trajeto até seu reconhecimento expresso pela Constituição Federal de 1988, que retirou do ordenamento jurídico a vergonhosa descriminação entre os filhos, dispondo em seu artigo 227, § $6^{\circ}$, que todos os filhos havidos ou não do casamento, ou por adoção, terão os mesmos direitos. ${ }^{51}$
Esses conceitos são importantes para compreender que, atualmente, a pessoa tem sido valorizada como indivíduo pertencente de uma unidade social, e, nesse sentido, a criança, bem como seus pais, merece e tem tantos direitos um quanto o outro e não é por estar numa situação de submissão ao poder familiar que ela pode ter suas liberdades restringidas por um mero desejo egoísta dos pais de atingir alguém que para ela tem grande valor. A criança e o adolescente têm direito a ter uma convivência familiar saudável, no meio daquelas pessoas que the tratam com carinho, respeito, e por quem elas têm admiração.

\subsection{Princípio da Convivência Familiar}

A convivência familiar e comunitária é direito garantido pelo Estatuto da Criança e do Adolescente, que prevê no seu art. 19, caput: "Toda criança ou adolescente tem direito a ser criado e educado no seio de sua família e, excepcionalmente, em família substituta, assegurada a

51 THOMÉ, Liane Maria Busnello. Dignidade da pessoa humana e mediação familiar. Porto Alegre: Livraria do Advogado, 2010, p. 74-75. 
convivência familiar e comunitária, em ambiente livre da presença de pessoas dependentes de substâncias entorpecentes."

Este é o direito/princípio que trata do cerne da questão da Alienação Parental, em que a criança é privada da convivência com um genitor ou alguém que lhe é importante. No geral ele é ferido em decorrência da ocorrência da separação dos pais, contudo "salutar é que a criança com o fim do relacionamento possa continuar desfrutando da convivência entre o pai e a mãe em igualdade de condições buscando dessa forma evitar o sentimento de abandono." ${ }{ }^{2}$

Paulo Lôbo ${ }^{53}$ menciona que "a Convenção dos Direitos da Criança, no art. 9.3, estabelece que, no caso de pais separados, a criança tem direito de 'manter regularmente relações pessoais e contato direto com ambos, a menos que isso seja contrário ao interesse maior da criança"”. E complementa, embora não menciona tratar de caso de alienação, situação que bem pertine ao assunto: "A convivência familiar também perpassa o exercício do poder familiar. Ainda quando os pais estejam separados, o filho menor tem direito à convivência familiar com cada um, não podendo o guardião impedir o acesso ao outro, com restrições indevidas". Esclarece, contudo, que tal direito não se restringe à pessoa dos pais, porque o núcleo familiar importante ao desenvolvimento da criança varia conforme os valores familiares, que podem incluir nas relações os tios, avôs e outros familiares.

A convivência passou a ter uma importância tão grande dentro do Direito de Família, que atualmente os advogados têm considerado a substituição do termo "direito de visita" para "direito de convivência", é o que ressalta o trecho abaixo:

Há muito que vem se discutindo acerca do alcance do denominado "direito de visitas", estando pacificado na doutrina abalizada brasileira, que a expressão "visitas" deve ser entendida como "convivência", e seguindo a orientação estabelecida na Convenção Universal dos Direitos da Criança e do Adolescente promovida

52 MAZZONI, Henata Mariana de Oliveira; MARTA, Taís Nader. Síndrome da Alienação Parental. Revista Brasileira de Direito das Famílias e Sucessões. Porto Alegre: Magister; Belo Horizonte: IBDFAM, 2007, ano XIII, $\mathrm{n}^{\circ} 21$, bimestral abr/mai 2011, p. 34.

53 LÔBO, Paulo. Direito Civil: famílias. 4. ed. São Paulo: Saraiva, 2011, p. 74-75. 
pela ONU, em 1989, que estabelece que o "direito de convivência" é direito dos filhos, e atendendo ao comando constitucional no art. 227 , que traz de forma expressa o direito fundamental à convivência familiar de forma mais abrangente possível, e o princípio da prioridade absoluta em relação aos direitos da criança $\mathrm{e}$ do adolescente, temos que concluir que o direito de convivência é uma via de mão dupla, sendo direito/dever do pai não guardião de conviver com o filho e do filho em conviver com o pai não guardião, com ênfase para o direito deste, em função do princípio da prioridade absoluta. ${ }^{54}$

Visitar $^{55}$ é situação eventual, sem interesse em aprofundar $o$ relacionamento, diferente de conviver ${ }^{56}$ em que há um vínculo de intimidade entre quem convive. Assim, o vínculo de convivência familiar é fundamental para que a criança tenha segurança para se desenvolver, pois é lá que ela tem seu refúgio, a quem ela recorre nos momentos mais diversos de sua vida.

\subsection{Princípio da Afetividade}

Para Maria Helena Diniz ${ }^{57}$ o "princípio da afetividade [é] corolário do respeito da dignidade da pessoa humana, como norteador das relações familiares e da solidariedade familiar".

Não é à toa que tal princípio tem direta ligação com o princípio da convivência familiar e do princípio do pluralismo, não abordado diretamente nesta pesquisa, mas característica

54 LIRA, Wlademir Paes de. Direito da Criança e do Adolescente à Convivência Familiar e uma Perspectiva de Efetividade no Direito Brasileiro. In: VII CONGRESSO BRASILEIRO DE DIREITO DE FAMÍLIA. Família e Responsabilidade - teoria e prática do Direito de Família. Coord. Rodrigo da Cunha Pereira, 7., 2009, Belo Horizonte. Anais... Porto Alegre: Magister/IBDFAM, 2010, p. 528.

55 VISITAR. In: MICHAELIS Moderno Dicionário da Língua Portuguesa. São Paulo: Melhoramentos, 1998. Disponível em: <http://michaelis.uol.com.br/moderno/portugues/ index.php?lingua=portugues-portugues\&palavra=visitar $>$. Acesso em: 14 jul. 2011.

56 CONVIVER. In: MICHAELIS Moderno Dicionário da Língua Portuguesa. São Paulo: Melhoramentos, 1998. Disponível em: <http://michaelis.uol.com.br/moderno/portugues/ index.php?lingua $=$ portugues-portugues\&palavra $=$ conviver $>$. Acesso em: 14 jul. 2011.

57 DINIZ, Maria Helena. Curso de Direito Civil Brasileiro, v. 5: Direito de Família. 25. ed. São Paulo: Saraiva, 2010, p. 24. 
da transformação da família. $O$ reconhecimento das entidades familiares formadas por uma pessoa e sua prole, e pela união estável, e a importância dada à convivência, demonstra que a ideia de família hoje é a união de pessoas com uma base diversa da patrimonial de outrora. É o que confirma Paulo Lôbo: ${ }^{58}$

A família recuperou a função que, por certo, esteve nas suas origens mais remotas: a de grupo unido por desejos e laços afetivos, em comunhão de vida. $\mathrm{O}$ princípio jurídico da afetividade faz despontar a igualdade entre irmãos biológicos e adotivos [art. $227, \S \S 5^{\circ}$ e $6^{\circ}$ da Constituição Federal] e o respeito a seus direitos fundamentais, além do forte sentimento de solidariedade recíproca, que não pode ser perturbada pelo prevalecimento de interesses patrimoniais. É o salto, à frente, da pessoa humana nas relações familiares.

Mas há um ponto que o autor aborda e que é fundamental que é o fato deste princípio não se confundir com o afeto $^{59}$ psicológico. Sua explanąção parece confusa, quando afirma que como princípio jurídico é imposto ainda que haja desamor ou desafeição entre pais e filhos ${ }^{60}$. $O$ que se entende pelo que o autor diz é que a afetividade está ligada à própria ideia do respeito, do dever se

58 LÔBO, Paulo. Direito Civil: famílias. 4. ed. São Paulo: Saraiva, 2011, p. 71.

59 "A afeição é um sentimento que se tem em relação a determinada pessoa ou algum bem. Afeiçoar-se significa identificar-se, ter afeto, amizade ou amor. Os membros de uma família, em sua maioria, possuem laços de afeição uns com os outros. Entretanto, isso não é uma realidade absoluta. Há entidades familiares desgraçadas por inimizades capitais e por relacionamentos praticamente nulos. Ora, nenhuma pessoa pode ser compelida a afeiçoar-se a outra, pouco importando se há entre elas algum parentesco ou não. Bom seria se todos tivessem afeto uns pelos outros, cumprindo assim o mandamento bíblico e de outras religiões não cristãs. Todavia, a complexidade das relações interpessoais muitas vezes leva a situações que impedem ou mesmo enfraquecem esse nível de relacionamento. $E$ não há qualquer poder temporal capaz de modificar esse quadro, compelindo uma pessoa a se afeiçoar por outra" (LISBOA, Roberto Senise. Manual de direito civil, v. 5: direito de família e sucessões. 5. ed. reform. São Paulo: Saraiva, 2009, p. 25, grifou-se)

60 LÔBO, Paulo. Direito Civil: famílias. 4. ed. São Paulo: Saraiva, 2011, p. 71. 
mútua assistência, e da liberdade no planejamento familiar, porque a partir do momento em que os indivíduos escolhem formar uma família eles têm que se responsabilizar pela sua existência e condução, seria a ideia do afeto como a de que a união se deu por ela e merece o cuidado peculiar de uma união que a princípio não tem por base interesse político, patrimonial ou religioso, embora tais pontos estejam presentes eles não são o fundamento da constituição familiar.

\subsection{Princípio do Melhor Interesse da Criança e do Adolescente}

O princípio do melhor interesse da criança e do adolescente, assim como outros, foi um resultado da evolução, de uma inversão de prioridade que tirou o foco do interesse na figura paterna, porque chefiava a família, para focar na figura dos filhos, pessoas dignas e em desenvolvimento, em que são projetadas as perspectivas para o futuro. Tanto que houve uma substituição do termo "pátrio poder", para "poder familiar", porque, atualmente, além do foco ter saído do pai para ir para o filho, à familia, em igualdade de condições, cabe a condução da vida das crianças e adolescentes. ${ }^{61}$

Giselle Câmara Groeninga ${ }^{62}$ tem uma ótica interessante sobre este princípio, ela diz que:

A família não mais pode ser pensada
de forma dividida, ela é um sistema
em que os integrantes exercem
funções complementares. Da mesma
forma, há uma confusão na divisão
que se faz ao falar do superior
interesse da criança e do adolescente
como se fosse contrário ao dos
pais. O que existe é, na realidade, o
superior interesse da família sendo
que, como sua função primordial é
a do atendimento e cuidado de seus
membros, priorizando-se o grau de
fragilidade de cada um, o interesse
da criança traduz, assim, a finalidade
primeira da família.

Para efetividade do melhor interesse da criança é preciso que os seus pais tenham a consciência de que são eles que viabilizam a vida dos filhos, lhes proporcionam uma realidade que

61 LÔBO, op. cit., p. 75.

62 GROENINGA, Giselle Câmara. Direito à Família. Boletim IBDFAM, Belo Horizonte, $\mathrm{n}^{\circ} 51$, ano 8., p. 3-5, jul./ago. 2008, p. 3. 
possibilita o desenvolvimento físico e psíquico saudável.

\subsection{Princípio da Paternidade Responsável}

A paternidade responsável é um dever de ambos os genitores. Sob as bases já traçadas nos princípios anteriormente mencionados. Diretamente ligado ao livre planejamento familiar abordado pelo art. $226^{\circ}, \S$ $7^{\circ}$, da Constituição Federal. ${ }^{63}$ Através dele a "a família deve outorgar aos filhos, havidos do casamento ou não, todos os meios para o pleno desenvolvimento de suas faculdades físicas, psíquicas e intelectuais." ${ }^{4}$

É fundado em todos os princípios esboçados anteriormente que a lei defere à família direitos e deveres tão fundados no bem-estar de seus membros, e que claramente priorizamse a criança e o adolescente.

\section{O SISTEMA PROTETIVO CONFERIDO À CRIANÇA E AO ADOLESCENTE}

Sob a ótica dos princípios gerais e específicos de direito de família vislumbra-se a existência de um campo seguro em que deveriam estar contidas as crianças e os adolescentes, e que por uma irresponsabilidade dos pais acabam por ser excluídos nos atoos de alienação. Cabe lembrar o que colocou-se no item a respeito do princípio do melhor interesse da criança, em que Giselle Câmara Groeninga $^{65}$ fala da família como una, em que cada integrante tem o seu papel, e um complementa o outro.

Nessa situação, de alienação parental, a criança e o adolescente, apesar de pessoa humana com dignidade garantida constitucionalmente, são tratados como coisa disponível ${ }^{66}$, um objeto

63 GONÇALVES, Carlos Roberto. Direito Civil Brasileiro, v. 6: Direito de Família. 8. ed. rev. e atual. São Paulo: Saraiva, 2011, p. 24.

64 LISBOA, Roberto Senise. Manual de direito civil, v. 5: direito de família e sucessões. 5. ed. reform. São Paulo: Saraiva, 2009, p. 17.

65 GROENINGA, Giselle Câmara. Direito à Família. Boletim IBDFAM, Belo Horizonte, $\mathrm{n}^{\mathrm{o}}$ 51, ano 8., p. 3-5, jul./ago. 2008, p. 3.

66 Conforme Paulo Lôbo: "A dignidade da pessoa humana é o núcleo existencial que é essencialmente comum a todas as pessoas humanas, como membros iguais do gênero humano, impondo-se um dever geral de respeito, proteção e intocabilidade. 
usado para atingir o fim de afastar ou punir o genitor alienado.

A Constituição ressalva os direito da criança e do adolescente (arts. $226 \$ 7^{\circ}$ e 227$)$, e, de certo modo, que é dever da família colocá-los a salvo dos atos de alienação parental, porque a criança e o adolescente têm direito à saúde (emocional inclusive), à dignidade, ao respeito $(\mathrm{e}$, portanto, de não se ver envolvido pelas brigas conjugais, que como tais referem-se ao casal e não à relação de parentalidade), à liberdade e à convivência familiar (o direito a livremente gostar e estar com ambos os pais e parentes, ter uma convivência sadia e sem empecilhos que demonstrem o firme egoísmo daqueles que sobre ela tenham autoridade). Além disso, expô-los aos malefícios da alienação parental é submetê-los a negligência, violência, crueldade e opressão, no mínimo.

\subsection{O Poder Familiar}

Trata-se o poder familiar de "múnus imposto pelo Estado aos pais". É o poder-dever conferido aos pais em relação aos filhos até completarem a maioridade (ou serem emancipados), com caráter protetivo, resguardado pela: inalienabilidade, irrenunciabilidade, imprescritibilidade e indisponibilidade ou indelegabilidade. ${ }^{67}$

A respeito do poder familiar o Código Civil de 2002 destinou os arts. 1.630 a 1.638 para tratar do assunto. Através destes dispositivos é possível depreender que o poder familiar é conferido a ambos os pais, sob os

Kant [KANT, Immanoel. Fundamentação da metafísica dos costumes. Trad. Paulo Quintela. Lisboa: Ed. 70, 1986, p. 77], em lição que continua atual, procurou distinguir aquilo que tem um preço, seja pecuniário, seja estimativo, do que é dotado de dignidade, a saber, do que é inestimável, do que é indisponível, do que não pode ser objeto de troca. Diz ele: 'No reino dos fins tudo tem ou um preço ou uma dignidade. Quando uma coisa tem um preço, pode-se pôr em vez dela qualquer outra como equivalente; mas quando uma coisa está acima de todo o preço, e, portanto, não permite equivalente, então tem ela dignidade" (LÔBO, Paulo. Direito Civil: famílias. 4. ed. São Paulo: Saraiva, 2011, p. 60).

67 NORONHA, Carlos Silveira. Da instituição do Poder Familiar, em perspectiva histórica, moderna e pós-moderna. Revista da Faculdade de Direito da Universidade Federal do Rio Grande do Sul, Porto Alegre, n 26, p. 89 - 120, dez. 2006. 
filhos menores. Além disso, também se verifica que não há término deste poder-dever quando houver separação (divórcio ou dissolução da união), e que nesses dispositivos encontram-se as determinações sobre a suspensão e extinção deste poder. $\mathrm{O}$ art. 1.634 é aquele em que se encontra o rol de competências relativas ao poder familiar, que, por ora, cumpre transcrevê-lo:

Art. 1.634. Compete aos pais, quanto à pessoa dos filhos menores:

I - dirigir-lhes a criação e educação;

II - tê-los em sua companhia e guarda;

III - conceder-lhes ou negar-lhes consentimento para casarem;

IV - nomear-lhes tutor por testamento ou documento autêntico, se o outro dos pais não lhe sobreviver, ou o sobrevivo não puder exercer o poder familiar;

V - representá-los, até aos dezesseis anos, nos atos da vida civil, e assistilos, após essa idade, nos atos em que forem partes, suprindo-lhes o consentimento;
VI - reclamá-los de quem ilegalmente os detenha;

VII - exigir que lhes prestem obediência, respeito e os serviços próprios de sua idade e condição.

O conceito de Pontes de Miranda é bem objetivo e claro quando diz que o pátrio poder moderno (moderno à sua época, mas que continua atual), é conferido a ambos os genitores, e não se trata ele de poder no sentido de imposição e violência, como ocorre nos atos de alienação:

O pátrio poder moderno é conjunto de direitos concedidos ao pai ou à própria mãe, a fim de que, graças a eles, possa melhor desempenhar a sua missão de guardar, defender e educar os filhos, formando-os e robustecendo-os para a sociedade e a vida. A expressão 'poder' tem sentido de exteriorização do querer, não de imposição e violência. ${ }^{68}$ (grifou-se).

Discutia-se, até o Código Civil de 2002 a alteração do termo "pátrio

68 PONTES DE MIRANDA. Tratado de Direito Privado - Parte Especial - Tomo IX - Direito de Família: Direito parental. Direito Protetivo. 4. ed. São Paulo: Revista dos Tribunais, 1974, p. 106-107. 
poder", que dizia respeito ao poder exercido pelo pai, chefe de família, a quem era direcionada a "posse" do filho, pensamento não mais cabível atualmente em que os direitos e deveres na educação e condução da vida dos filhos incapazes diz respeito a ambos os pais, e não mais uma exclusividade do homem. "A necessidade de o Estado regular a relação existente entre os pais e seus filhos, com base na evolução do que antes se via no pátrio poder, levou o legislador civilista de 2002 a abraçar o termo poder familiar [art. 1634 do Código Civil] [...]" ${ }^{69}$ Como já dito anteriormente, achou-se por bem alterar o termo face à substituição do foco, antes no chefe da família, o pai, para o filho, sob responsabilidade da família. ${ }^{70}$

Nesse sentido, é fundamental ter em mente que o poder familiar referese a um direito-dever dos pais de ter os filhos em sua companhia, e de conduzir suas vidas, independentemente da relação de conjugalidade. Esse poder não acaba com a separação, ou o fim da relação dos pais, primeiro porque o fim de uma relação conjugal não implica o fim da relação de parentalidade, segundo porque, neste caso, apenas a presença física do filho é que determinada pela guarda. Ou seja,

Durante o período de tempo em que durar o casamento ou a união estável, compete a ambos os pais o exercício do poder familiar, sendo que, com a sua dissolução, não há alteração das relações existentes entre pais e filhos, senão quanto ao direito, que aos pais cabe, de terem em sua companhia os filhos, ou seja, com a dissolução da família, o poder familiar de ambos os pais continua a ser exercido conjuntamente, contudo, salvo o caso da guarda compartilhada, apenas um dos genitores será responsável pela guarda do menor, enquanto ao outro restará o direito convivencial..$^{11}$

$\mathrm{O}$ próprio Estatuto da Criança e do Adolescente no art. 21 fala em poder familiar exercido pelo pai e pela mãe, em igualdade de condições, mas não se refere à sua situação como namorados, conviventes, casados, separados, etc. Apesar do Código Civil, em seu art. 1.631, falar ser exercido durante o casamento ou a

69 FIGUEIREDO, Fábio Vieira; ALEXANDRILIS, Georgios. Alienação Parental: aspectos materiais e processuais da Lei $\mathrm{n}^{\circ}$ 12.318, de 26.08.2010. São Paulo: Saraiva, 2011, p. 13.

70 LÔBO, Paulo. Direito Civil: famílias. 4. ed. São Paulo: Saraiva, 2011, p. 75.

71 FIGUEIREDO, op. cit., p. 15. 
união estável, o poder familiar não extingue com a separação. ${ }^{72}$

De outro modo há a possibilidade de perda do poder familiar, determinada pelo descumprimento dos deveres a ele inerentes (art. 22 do Estatuto da Criança e do Adolescente) ou através da adoção, caso em que é extinto dos pais biológicos para ser transferido aos adotantes:

A adoção também gera a extinção do poder familiar, já que o menor passa a integrar a família do adotante, sendo reconhecido como filho, sem qualquer distinção ou discriminação quanto à origem adotiva da filiação transmitindo aos pais adotivos o poder familiar. $^{73}$

Sendo assim, as responsabilidades dos pais perdura mesmo sem estes conviverem, e este é um ponto muito importante de ser lembrado. O excasal não pode, nem deve, entender que na separação o filho pertencerá a um deles somente. Não se trata a criança e o adolescente de objeto pertencente, mas de ser humano que tem prioridades, nesse sentindo as decisões continuam sendo tomadas pelos dois genitores, que ao divergirem podem recorrer ao Judiciário, para uma decisão, ou seja:

Pertence aos pais a escolha do tipo de educação escolar que desejam para seus filhos. Cabe-lhes decidir sobre o ensino público ou privado, o tipo de orientação pedagógica ou religiosa, o modelo escolar mais adequado. A escolha da educação depende de circunstâncias econômicas e do nível de renda dos pais. A Convenção Internacional dos Direitos da Criança estabelece a liberdade dos pais para a educação e orientação religiosas dos filhos. Em caso de desacordo, qualquer dos pais poderá recorrer ao juiz, que deve leva em conta as práticas anteriores e o fato de a escolha poder submeter a criança a risco de desequilíbrios emocionais. ${ }^{74}$

Há uma certa confusão entre este instituto e o instituto da guarda, que oportuniza o entendimento de que poder familiar é deferido para um dos pais ou ambos conforme a guarda, unilateral ou compartilhada. Mas tal entendimento é errôneo, de acordo

72 VENOSA, Sílvio de Salvo. Direito civil, v. 6: direito de família. 11. ed. São Paulo: Atlas, 2011, p. 306.

73 FIGUEIREDO, op. cit., p. 32.

74 LÔBO, Paulo. Direito Civil: famílias. 4. ed. São Paulo: Saraiva, 2011, p. 303. 
com Paulo Lôbo ${ }^{75}$, a proteção dos filhos é direito e dever de ambos os pais, e a guarda estaria no direito de continuar vivendo com o filho, ou de conviver com ele, o autor conclui dizendo que: "[...] Os pais preservam os respectivos poderes familiares em relação aos filhos, com a separação, e os filhos preservam o direito de acesso a eles e ao compartilhamento recíproco de sua formação.".

Veja-se, então, o que seria especificamente a guarda.

\subsection{A Guarda}

A alienação ocorre no geral em processos de guarda, que decorrem de uma separação/divórcio. ${ }^{76}$ Inclusive, é o que afirma o próprio Richard Gardner ${ }^{77}$, criador do termo Síndrome da Alienação Parental (SAP).

A guarda é a regularização da posse de fato da criança ou adolescente, que obriga à prestação de assistência material, moral e educacional (art. 33 do Estatuto da Criança e do Adolescente). Ela é deferida a quem tenha melhor condições para exercê-la. Tanto que há alguns anos era natural se pensar que a mãe era quem detinha as melhores qualidades para criar $o$ filho, seja porque este antigamente era seu papel mais importante, seja por ser ela a os gestar. Mas esta visão

75 LÔBO, op. cit., p. 190.76 OLIVEIRA, Euclides de. Alienação Parental. In: III CONGRESSO BRASILEIRO DE DIREITO DE FAMÍLIA - Família e Responsabilidade: teoria e prática do direito de família, 7., 2009, Belo Horizonte. Anais... Porto Alegre: Magister/IBDFAM, 2010, p. 231.

77 "Parental alienation syndrome (PAS, Gardner, 1985., 1986, 1987a, 1987b, 1989, $1992,1998)$ is a disorder thar arises almost exclusively in the context of childcustody disputes. In this disorder, one parent (the alienator, the alienating parent, the PAS-inducing parent) induces a program of denigration against the other parent (the alienation parent, the victim, the denigrated parent). However, this is not simply a matter of 'brainwashing' or 'programming' in that the children contribute their own elements into the campaign of denigration. It is this contribution of factors that justifiably warrants the designation PAS.[...]" (GARDNER, Richard A. Differentianting between parental alienation syndrome and bona fide abuseneglect. In: The American Journal of Family Therapy, apr/jun 1999, 27, 2, ProQuest Psychology Journal, p. 97) 
do papel da mulher sofreu profunda alteração após a última grande guerra, como destaca o Prof. Dr. Carlos Silveira Noronha ${ }^{78}$ :

É induvidoso que a família moderna passa por uma profunda evolução e para isso vêm contribuindo inúmeros fatores que se acentuaram a partir da última grande guerra, quando um de seus membros fundamentais - a mulher, esposa e mãe - partiu para trabalhar fora do lar, inicialmente para suprir a falta do marido presente nos campos de batalha e, terminando o conflito, para compensar no orçamento doméstico os influxos da economia dos países combalida pela guerra. Quando esse não tenha sido o caso, ocorre que ordinariamente precisa a mulher exercer atividade laborativa fora do lar para auxiliar o marido a implementar as despesas da família, em razão dos desajustes que atingem o macrossistema econômico da nação, com reflexos acentuados na economia da família.

A guarda pode ser unilateral ou compartilhada. Unilateral quando concedida a uma só pessoa. Compartilhada quando concedida ao pai e à mãe que não convivam. Ela diz respeito à responsabilização pela saúde, educação e necessidades imediatas do filho, aquelas que precisam de alguém que a viabilize. Assim, na guarda unilateral há um responsável e o outro age como um supervisor, ou seja, embora ambos tenham o poder familiar de garantir ao filho condições dignas de vida, a um deles é deferida a convivência diária, e o outro a convivência mais esporádica, desta feita, aquele que tem a güarda pode tomar as decisões que entender pertinente, contanto que não fira os direitos da criança $\mathrm{e}$ do outro genitor. A guarda compartilhada pressupõe, portanto, as decisões "diárias" (por exemplo, qual colégio colocar) conjuntas, podendo, mas não sendo obrigado, a determinação da presença física do filho seja também compartilhada ou permaneça com um deles (art. 1.583 do Código Civil).

A determinação da guarda pode ser por consenso dos pais ou determinação do juízo (art. 1.584 do Código Civil).

$O$ fato é que nas separações os adultos precisam distinguir a conjugalidade/convivência da parentalidade e quando não o conseguem acabam, por vezes, inserindo

78 NORONHA, Carlos Silveira. Conceito e fundamentos de família e sua evolução na área jurídica. Revista da Faculdade de Direito da Universidade Federal do Rio Grande do Sul, Porto Alegre, n 10, p. 161 - 174, jul. 1994, p. 167. 
na criança todas as suas frustrações. Muito bem coloca Luiz Edson Fachin que:

Uma das grandes tarefas dos processos de terminação do vínculo, quer seja socioafetivo, quer seja apenas formal para as uniões matrimonializadas, é evidenciar que se os pais se separam, os pais não devem se separar dos filhos. A guarda, tanto a unilateral quanto a compartilhada, deve espelhar um exercício diário de autocrítica para não despejar sobre as crianças ou adolescentes a discórdia entre os pais. ${ }^{79}$

Tanto é no sentido desta distinção que Fachin $^{80}$ inclui um novo princípio no rol dos já mencionados oportunamente, que seria o princípio da dissociação do estado de filiação com o estado civil dos pais:

"São colacionados diversos princípios, à luz da concepção codificada, da visão de mundo e do sistema tanto do Código novo quanto da Constituição, dentre eles:

a) dissociação do estado de filiação com o estado civil dos pais (seguindo orientação jurisprudencial do Superior Tribunal de Justiça); eis aí um dos elementos estruturantes da nova disciplina constitucional da filiação que se projetou sobre a jurisprudência e que, agora, vem recolhido, pelo novo Código Civil brasileiro [...]"

Observando-se que a guarda poder ser deferida a terceiro, caso entenda o juiz que é o melhor para a criança ou o adolescente. ${ }^{81}$

$O$ fato é que nos casos de alienação parental, há quem diga que a melhor decisão, do juízo (já que nesses casos não há consenso dos pais), seria a guarda compartilhada. Sob o argumento de que é através dela que ambos os genitores tenham responsabilidades em equilíbrio

79 FACHIN, Luiz Edson. Desafios e Perspectivas do Direito de Família no Brasil Contemporâneo. p. 423 - 443 In: JUNQUEIRA DE AZEVEDO, Antônio; TÔRRES, Heleno Taveira; CARBONE, Paolo (coord.). Princípios do Novo Código Civil Brasileiro e Outros Temas - Homenagem a Tullio Ascarelli. São Paulo, Quartier Latin, 2008, p. 434.

80 FACHIN, op. cit., p. 428.

81 MAGALHÃES FILHO, Sérgio de. Guarda Compartilhada entre Mãe e Tio. Boletim IBDFAM, Belo Horizonte, $n^{\circ}$ 51, ano 8., p. 3-5, jul./ago. 2008, p. 9. 
de condições, cumprindo o poder familiar conjuntamente. ${ }^{82} \mathrm{O}$ problema da guarda unilateral estaria na possibilidade do guardião dificultar ou proibir a convivência entre os filhos e o outro genitor, impedindo as visitas, sob a acusação de que o outro o negligencia, ao filho, e que o afastamento é uma forma de protegê-lo. ${ }^{83} \mathrm{O}$ fato é que ainda que sobre esses argumentos, imagina-se a dificuldade de conceder a guarda compartilhada, que pressupõe decisões consentidas, a duas pessoas que encontram-se em conflito.

\subsection{Os benefícios trazidos pela Lei da Alienação Parental (Lei $n^{\circ}$ 12.318/2010)}

A lei veio como um meio de esclarecer os meandros desse ato que preocupa por poder causar tantos danos à criança e ao adolescente. Ela fala diretamente sobre alguns dos direitos fundamentais que são feridos diante do ato de alienação e que, portanto, precisam ser respeitados, seguem alguns dispositivos da lei:

\section{[...]}

Art. $3^{\circ} \mathrm{A}$ prática de ato de alienação parental fere direito fundamental da criança ou do adolescente de convivência familiar saudável, prejudica a realização de afeto nas relações com genitor e com o grupo familiar, constitui abuso moral contra a criança ou o adolescente e descumprimento dos deveres inerentes à autoridade parental ou decorrentes de tutela ou guarda.

Art. $4^{\circ}$ Declarado indício de ato de alienação parental, a requerimento ou de ofício, em qualquer momento processual, em ação autônoma ou incidentalmente, $o$ processo terá tramitação prioritária, e o juiz determinará, com urgência, ouvido o Ministério Público, as medidas provisórias necessárias para preservação da integridade psicológica da criança ou do adolescente, inclusive para assegurar sua convivência com genitor ou viabilizar a efetiva

82 OLIVEIRA, Euclides de. Alienação Parental. In: III CONGRESSO BRASILEIRO DE DIREITO DE FAMÍLIA - Família e Responsabilidade: teoria e prática do direito de família, 7., 2009, Belo Horizonte. Anais... Porto Alegre: Magister/IBDFAM, 2010, p. 235.

83 DUARTE, Lenita Pacheco Lemos. Qual a posição da criança envolvida em denúncias de abuso sexual quando o litígio familiar culmina em situações de alienação parental: inocente, vítima ou sedutora?. In: . Incesto e Alienação Parental realidades que a Justiça insiste em não ver. Coordenação de Maria Berenice Dias. São Paulo: Editora Revista dos Tribunais, 2010, p. 108 e 113. 
reaproximação entre ambos, se for o caso.

Parágrafo único. Assegurar-se-á à criança ou adolescente e ao genitor garantia mínima de visitação assistida, ressalvados os casos em que há iminente risco de prejuízo à integridade física ou psicológica da criança ou do adolescente, atestado por profissional eventualmente designado pelo juiz para acompanhamento das visitas.

Além disso, vem exemplificando atos que podem configurar a alienação parental, o que auxilia os operadores do direito na observância dessas ocorrências, para, se for o caso, poder agir a respeito.

A lei garante a cautelosa avaliação da situação fática em que foi levantada a possibilidade de alienação, inclusive através de perícia feita por profissional de áreas como a psicologia e a assistência social ou por equipe multidisciplinar (art. $5^{\circ} \mathrm{da}$ Lei $\mathrm{n}^{\circ} 12.318 / 2010$ ).

De outro modo, a lei, verificada a alienação, determina que o juiz analise o fato e determine a atribuição da guarda ao genitor que melhores condições tenha de proporcionar à criança ou ao adolescente, inclusive, a convivência com o outro, de modo saudável, isto quando não for possível a guarda compartilhada (art. $7^{\circ}$ da Lei $\mathrm{n}^{\circ} 12.318 / 2010$ ).

Fábio Botelho $\mathrm{Egas}^{84}$, advogado especialista em direito de família, coloca em seu artigo opinião a respeito da Lei da Alienação Parental:

Contudo, deixa a nova lei de ir além naquilo que talvez seja da maior importância nesse momento em que especialmente a criança apresentase na sociedade como objeto, fruto de um projeto pessoal do adulto, que é a conscientização acerca da maternidade e da paternidade. A lei fresca repete o modelo já esgotado de crime e castigo. Reascende questões maniqueistas, novamente dando espaço para questões de culpas, deixando de lado a responsabilização por escolhas feitas, inclusive de ter um filho com alguém. (grifou-se)

De certo modo, Egas tem razão quando fala que é preciso uma conscientização da maternidade e da paternidade, é o que se depreende do princípio da paternidade responsável e do conceito que se tem da expressão planejamento familiar. Os genitores 
para o serem precisam compreender o papel a que se dispõem. Não basta apenas gerar um filho e colocá-lo no mundo sem se responsabilizar pelo suporte dele enquanto incapaz.

A Lei da Alienação Parental, veio, de certo modo, alertar a sociedade para essa responsabilização que os pais podem sofrer quando negligenciam os filhos.

\section{CONCLUSÃO}

O Direito vem atender à realidade atual da sociedade, por este motivo não basta que os aplicadores do Direito e sociedade o antevejam como norma petrificada nas palavras que o legislador determinou, é preciso que se tenha uma visão do todo, uma interpretação que leve em conta o texto da lei, os princípios e regras constitucionais, a situação de fato, de forma conjunta. E nesse sentido não seria diferente a necessidade do Direito de Família no que tange às garantias de crianças e adolescentes que sofrem ou não atos de alienação.

Não basta entender que o poder familiar o é, em seu sentido literal, um poder sem limites, conferido aos pais para comandar a vida dos filhos, mas uma parte de uma autoridade que vem envolta em alguns importantes deveres: de preservar sua saúde física e psíquica; de possibilitar que crianças ou adolescentes tenham uma existência digna, com o carinho de ambos os pais, e daqueles que lhes são importantes; de propiciar-lhe alimentação, e tudo aquilo que seja necessário ao seu sustento; de protegêlos dos riscos morais e daquilo que possa prejudicar sua convivência em comunidade.

O princípio da dignidade da pessoa humana e da paternidade responsável são de certo modo um alerta para a observância de todos os demais princípios, viabilizados pelos textos da Constituição, do Código Civil, do Estatuto da Criança e do Adolescente e da Lei de Alienação Parental, dentre outras não mencionadas nesta pesquisa.

É preciso deixar claro que todos os cidadãos têm responsabilidade sobre o que ocorre na vida em comunidade, e que não há como se vislumbrar um futuro digno se se deixam de lado direitos e garantias básicas, principalmente relativos a crianças e adolescentes, os quais determinou-se constitucionalmente serem pessoas em desenvolvimento, e, portanto, com prioridade. 


\section{REFERÊNCIAS}

ALVES, Leonardo Barreto Moreira. Temas Atuais de Direito de Familia - atualizado de acordo com as leis de números 12.004/09 e 12.010/09. Rio de Janeiro: Lumen Juris, 2010.

BEVILAQUA, Clóvis. Direito da Família. 7. ed. São Paulo: Editora Rio, 1976.

BRANDES, Joel R.. Parental Alienation. New York Journal, New York, 26 mar. 2000. Disponível em: <http://www.fact.on.ca/Info/ pas/brande00.htm\#FN4>. Acesso em: 1 jul. 2011.

BRASIL. Constituições Anteriores de 1824 a 1967 EMC no 1 de 1969. Diário Oficial da União, Poder Executivo, Brasília, DF. Disponível em: <http://www4. planalto.gov.br/legislacao/ legislacao-historica/constituicoesanteriores-1\#content>. Acesso em 23 jun. 2011.

BRASIL. Constituição da República Federativa do Brasil. Diário Oficial da União, Poder Executivo, Brasília, DF, 05 out. 1988. Disponível em: <http:// www.planalto.gov.br/ccivil_03/ Constituicao/Constituicao.htm>. Acesso em 23 jun. 2011.

BRASIL. Código Civil. Diário Oficial da União, Poder Executivo, Brasília, DF, 11 jan. 2002. Disponível em: <http://www.planalto.
gov.br/ccivil/leis/2002/L10406. htm>. Acesso em 17 jun. 2011.

BRASIL. Constituição da República Federativa do Brasil. Diário Oficial da União, Poder Executivo, Brasília, DF, 05 out. 1988. Disponível em: <http:// www.planalto.gov.br/ccivil_03/ constituicao/constituicao.htm>. Acesso em 17 jun. 2011.

BRASIL. Estatuto da Criança e do Adolescente. Diário Oficial da União, Poder Executivo, Brasília, DF, 16 jul. 1990. Disponível em: <http://www.planalto.gov. br/ccivil_03/Leis/L8069.htm>. Acesso em 17 jun. 2011.

BRASIL. Lei $\mathrm{n}^{\circ} 12.318$, de 26 de agosto de 2010. Diário Oficial da União, Poder Executivo, Brasília, DF, 27 ago. 2010. Disponível em: <http://www.planalto.gov.br/ ccivil_03/_Ato2007-2010/2010/ Lei/L12318.htm>. Acesso em 17 jun. 2011.

BRASIL. Projeto de Lei $\mathrm{n}^{\circ} 4.053$. Diário Oficial [da] República Federativa do Brasil, Poder Executivo, Brasília, DF, 07 out. 2008. Disponível em: <http:// www.camara.gov.br/sileg/ integras/601514.pdf $>$. Acesso em: 29 jun. 2011.

BRASIL, Tribunal de Justiça do Rio Grande do Sul. Apelação Cível n. 70017390972 - RS. Apelante: 
A.S. E M.O.P.S.. Apelado: E.A.L.C.. Relator: Luiz Felipe Brasil Santos, Porto Alegre, RS, 13 de junho de 2007. Disponível em: $\quad<$ http://www1.tjrs.jus.br/ busca/?tb=juris $>$ Acesso em: 01 nov. 2010.

BRASIL, Tribunal de Justiça do Rio Grande do Sul. Agravo de Instrumento n. 70014814479 RS. Agravante: G.S.A.. Agravado: T.M.W.. Relatora: Maria Berenice Dias, Porto Alegre, RS, 07 de junho de 2006. Disponível em: $<$ http://www1.tjrs.jus.br/busca/?q $=$ aliena $\%$ E $7 \%$ E3o+parental\&tb= jurisnova\&pesq $=$ ementario\&part ialfields $=\% 28$ TipoDecisao $\% 3 \mathrm{Aa}$ c $\% 25 \mathrm{C} 3 \% 25 \mathrm{~B} 3 \mathrm{rd} \% 25 \mathrm{C} 3 \% 25 \mathrm{~A} 3$ о\%7CTipoDecisao\%3Amonocr\% 25C3\% 25Altica\%29\&required fields $=\&$ as_q $=\& i n i=30>$. Acesso em: 01 jul. 2011.

BRASIL, Tribunal de Justiça do Rio Grande do Sul. Agravo de Instrumento n. 70015224140 RS. Agravante: M.S.S.. Agravado: S.D.A.. Relatora: Maria Berenice Dias, Porto Alegre, RS, 12 de julho de 2006. Disponível em: $<$ http://www1.tjrs.jus.br/busca/? $\mathrm{q}=$ aliena $\% \mathrm{E} 7 \% \mathrm{E} 3 \mathrm{o}+$ parental\&tb =jurisnova\&pesq=ementario\&pa rtialfields $=\% 28$ TipoDecisao $\% 3 \mathrm{~A}$ ac\%25C3\%25B3rd\%25C3\%25A 3o\%7CTipoDecisao\%3Amonocr $\% 25 \mathrm{C} 3 \% 25 \mathrm{~A} 1$ tica\%29\&required fields $=\&$ as_ $q=\&$ ini $=30>$. Acesso em: 01 jul. 2011.

BRASIL, Tribunal de Justiça do Rio Grande do Sul. Apelação Cível n. 70017390972 - RS. Apelante: A.S.. Apelado: E.A.L.C.. Relator: Luiz Felipe Brasil Santos, Porto Alegre, RS, 13 de junho de 2006. Disponível em: <http://www1. tjrs.jus.br/busca/?q=aliena\%E7 $\% \mathrm{E} 3 \mathrm{o}+$ parental $\& \mathrm{tb}=$ jurisnova \&pesq=ementario\&partialfield $\mathrm{s}=\% 28 \mathrm{TipoDecisao} \% 3 \mathrm{Aac} \% 25$ C3\%25B3rd\%25C3\%25A30\% 7CTipoDecisao\%3Amonocr\% 25C3\%25A1tica\%29\&required fields $=\&$ as_q $=\&$ ini $=20>$. Acesso em: 01 jul. 2011.

BRASIL, Tribunal de Justiça do Rio Grande do Sul. Agravo de Instrumento n. 70028169118 RS. Agravante: V.O.. Agravado: H.N.G.. Relator: André Luiz Planella Villarinho, Porto Alegre, RS, 11 de março de 2009. Disponível em: <http://wwwl. tjrs.jus.br/busca/?q=aliena $\%$ E7 $\% \mathrm{E} 3 \mathrm{o}+$ parental\&tb=jurisnova \&pesq=ementario\&partialfield $\mathrm{s}=\% 28 \mathrm{TipoDecisao} \% 3 \mathrm{Aac} \% 25$ C3\%25B3rd\%25C3\%25A3o\% 7CTipoDecisao\%3Amonocr\% 25C3\%25A 1 tica\%29\&required fields $=\&$ as_q $=\&$ ini $=20>$. Acesso em: 01 jul. 2011.

CONVIVER. In: MICHAELIS Moderno Dicionário da Língua Portuguesa. São Paulo: Me- 
lhoramentos, 1998. Disponível em: <http://michaelis.uol. com.br/moderno/portugues/ index.php?lingua $=$ portugues-portugues\&palavra=conviver $>$. Acesso em: 14 jul. 2011.

DIAS, Maria Berenice. Manual de Direito das Famílias. 5.ed. rev. atual. e ampl. São Paulo: Revista dos Tribunais, 2009.

DIAS, Maria Berenice. (Coord.). Incesto e Alienação Parental. 2.ed. rev. atual. e ampl. São Paulo: Revista dos Tribunais, 2010.

DIAS, Maria Berenice. Síndrome da alienação parental, o que é isso?. Disponível em: <http:// www.mbdias.com.br/hartigos. aspx?112,24>. Acesso em 28 out. 2010.

DINIZ, Maria Helena. Curso de Direito Civil Brasileiro, v. 5: Direito de Família. 25. ed. São Paulo: Saraiva, 2010.

DUCOTE, Richard. A comment about Dr. Richard Gardner's suicide released by the last man to cross examine him, attorney Richard Ducote. Site Cininnatipas. com. Jun. 2003. Disponível em: $<\mathrm{http}$ ://cincinnatipas.com/drrichardgardnerautopsy.html> Acesso em: 23 jun. 2011

EGAS, Fábio Botelho. Alienação parental, a Lei $\mathrm{n}^{\mathrm{o}} 12.318 / 10$. Revista Visão Jurídica, $\mathrm{n}^{0}$ 55, sem ano, São Paulo, Editora Escala, p. 67.
FACHIN, Luiz Edson. As Intermitências da Vida - O Nascimento dos Não-Filhos à Luz do Código Civil Brasileiro. 1.ed. Rio de Janeiro: Forense, 2007, 95 p.

FACHIN, Luiz Edson. Desafios e Perspectivas do Direito de Família no Brasil Contemporâneo. p. 423 - 443 In: JUNQUEIRA DE AZEVEDO, Antônio; TÔRRES, Heleno Taveira; CARBONE, Paolo (coord.). Princípios do Novo Código Civil Brasileiro e Outros Temas - Homenagem a Tullio Ascarelli. São Paulo, Quartier Latin, 2008.

FACHIN, Luiz Edson. Elementos críticos do Direito de Família: curso de direito civil. Rio de Janeiro: Renovar, 1999. 346 p.

FIGUEIREDO, Fábio Vieira; ALEXANDRILIS, Georgios. Alienação Parental: aspectos materiais e processuais da Lei $\mathrm{n}^{\circ}$ 12.318, de 26.08.2010. São Paulo: Saraiva, 2011, p. 13.

GABRIEL, Sérgio. O papel dos princípios no Direito brasileiro e os princípios constitucionais. Jus Vigilantibus, São Paulo, 23 jul. 2007. Disponível em: $<\mathrm{http}$ // jusvi.com/artigos/29789>. Acesso em: 07 jul. 2011.

GONÇALVES, Carlos Roberto. Direito Civil Brasileiro, v. 6: Direito de Familia. 8. ed. rev. e atual. São Paulo: Saraiva, 2011. 
GROENINGA, Giselle Câmara. O Fenômeno da Alienação Parental. In: PEREIRA, Rodrigo da Cunha; MADALENO, Rolf. Direito de Família: processo, teoria e prática. Rio de Janeiro: Forense, 2008. p. 117-139

GROENINGA, Giselle Câmara. Direito à Família. Boletim IBDFAM, Belo Horizonte, $\mathrm{n}^{\circ} 51$, ano 8., p. 3-5, jul./ago. 2008, p. 3. IMEPA, Textos do Dr. Richard Gardner. Tradução de Rita de Cássia Rafaeli Neto. Disponível em <http://www. mediacaoparental.org/gardner. php>. Acesso em 03 nov. 2010.

KRAUSS, Daniel A.; Lieberman, Joel. D. Psychological Expertise in Court: psychology in the courtroom, v. II. United States: Ashgate, 2009. p. 113.

LAGO, Vivian de Medeiros; BANDEIRA, Denise Ruschel. A Psicologia e as Demandas Atuais do Direito de Família. Psicologia Ciência e Profissão, Porto Alegre, 29 (2), p. 290-305, 2009.

LIRA, Wlademir Paes de. Direito da Criança e do Adolescente à Convivência Familiar e uma Perspectiva de Efetividade no Direito Brasileiro. In: VII CONGRESSO BRASILEIRO DE DIREITO DE FAMÍLIA. Família e Responsabilidade - teoria e prática do Direito de Família.
Coord. 14,7Horizonte: IBDFAM, 2007, ano XIII, $\mathrm{n}^{\circ} 21$, bimestral abr/mai 2011, p. 33-51.

NORONHA, Carlos Silveira. Da instituição do Poder Familiar, em perspectiva histórica, moderna e pós-moderna. Revista da Faculdade de Direito da Universidade Federal do Rio Grande do Sul, Porto Alegre, $\mathrm{n}^{\circ}$ 26, p. 89 - 120, dez. 2006.

NORONHA, Carlos Silveira. Conceito e fundamentos de família e sua evolução na área jurídica. Revista da Faculdade de Direito da Universidade Federal do Rio Grande do Sul, Porto Alegre, ${ }^{\circ} 10$, p. 161 - 174, jul. 1994.

OLIVEIRA, Euclides de. Alienação Parental. In: VII CONGRESSO BRASILEIRO DE DIREITO DE FAMÍLIA. Família e Responsabilidade - teoria e prática do Direito de Família. Coord. Rodrigo da Cunha Pereira, 7., 2009, Belo Horizonte. Anais... Porto Alegre: Magister/IBDFAM, 2010, p. 231-255.

ONU. Declaração Universal dos Direitos Humanos. Rio de Janeiro, dez. 2000. Disponível em: <http:// unicrio.org.br/img/DeclU_D_ Humanos VersoInternet.pdf $>$ Acesso em: 12 jul. 2011.

PEREIRA, Caio Mário da Silva, Reconhecimento de paternidade e seus efeitos. 5. ed. Rio de Janeiro: 
Forense, 1996, p. 8 apud FUJITA, 2009, p. 13.

PEZZELLA, Maria Cristina Cereser; SILVA, Fernanda Pappen da. Os Seres Sujeitos de Direitos em Família. In: SILVA FILHO, José Carlos Moreira da; PEZZELLA, Maria Cristina Cereser (coords.). Mitos e Rupturas no Direito Civil Contemporâneo. Rio de Janeiro: Lumen Juris, 2008, p. 325 a 353.

PODEVYN, François (04/04/2001).

Síndrome de Alienação Parental. Tradução para Português: Apase - Associação de Pais e Mães Separados (08/08/2001) e Associação Pais para Sempre. Disponível em <http://www. apase.org.br/94001-sindrome. htm>. Acessado em 07 nov. 2010. PONTES DE MIRANDA. Tratado de Direito Privado - Parte Especial - Tomo IX - Direito de Família: Direito parental. Direito Protetivo. 4. ed. São Paulo: Revista dos Tribunais, 1974. RIZZARDO, Arnaldo. Direito de Familia: Lei $n^{o}$ 10.406, de 10.01.2002. 7.ed. rev. e atual. Rio de Janeiro: Forense, 2009.

SOLIDARIEDADE. In: MICHAELIS Moderno Dicionário da Língua Portuguesa. São Paulo: Melhoramentos, 1998. Disponível em: <http://michaelis.uol.com. $\mathrm{br} /$ moderno/portugues/index. php?lingua $=$ portugues-portugues \&palavra $=$ solidariedade $>$. Acesso em: 13 jul. 2011.

SOMMER, Reena. Parental Alienation Syndrome. Divorcing Mistakes.com, Texas, 2004. Disponível em: <http://www. divorcingmistakes.com/articles/ PASreview.pdf $>$. Acesso em 01 jul. 2011.

SOUZA, Euclydes de. Jurisprudência "Melhor Interesse da Criança" - Pailegal.net. Disponível em: http://www.pailegal.net/chicus. asp? rvTextoId $=-236521748$. Acesso em: 8 de julho de 2010 .

SOUZA, Monaliza Costa de et al. O papel do advogado na alienação parental. In: SOUZA, Monaliza Costa de et al. Família contemporânea: uma visão interdisciplinar. Coordenação de Ivone M. Candido Coelho de Souza. Porto Alegre: IBDFAM: Letra\&Vida, 2011, p. 168-176.

THOMÉ, Liane Maria Busnello. Dignidade da pessoa humana $e$ mediação familiar. Porto Alegre: Livraria do Advogado, 2010.

TRINDADE, Jorge. Síndrome de Alienação Parental. In: DIAS, Maria Berenice (Coord.). Incesto e Alienação Parental. 2.ed. rev. atual. e ampl. São Paulo: Revista dos Tribunais, 2010. p. 21-32

ULLMANN, Alexandra. Síndrome da Alienação Parental. Revista Visão Jurídica, $\mathrm{n}^{\circ}$ 30. São Paulo, 2008, p. 62-65. 
VENOSA, Sílvio de Salvo. Direito civil, v. 6: direito de família. 11. ed. São Paulo: Atlas, 2011.

VISITAR. In: MICHAELIS Moderno Dicionário da Língua Portuguesa. São Paulo: Melhoramentos, 1998.
Disponível em: $<\mathrm{http}: / /$ michaelis. uol.com.br/moderno/portugues/ index.php?lingua=portuguesportugues\&palavra=visitar $>$. Acesso em: 14 jul. 2011. 
$\because$ 